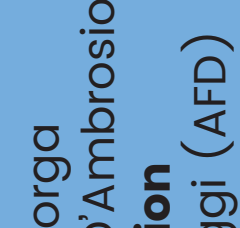

$$
\begin{aligned}
& \text { ๓ } \\
& \text { क } 3 \text { 을 응 } \\
& \text { 을 屯들 을 } \\
& \text { 득 은은 } \\
& \text { భ. }
\end{aligned}
$$

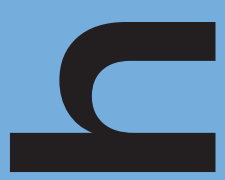

Social

Protection

and Multi-

dimensional

Poverty:

Lessons from

Ethiopia, India

and Peru

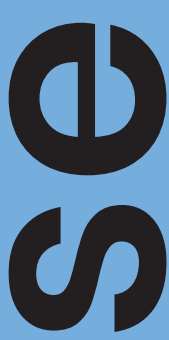

(a)
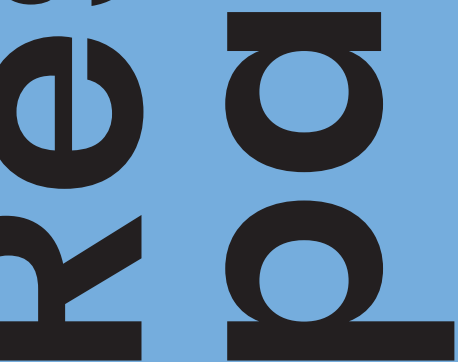


\section{Agence française de développement}

\section{Papiers de recherche}

Les Papiers de Recherche de l'AFD ont pour but de diffuser rapidement les résultats de travaux en cours. Ils s'adressent principalement aux chercheurs, aux étudiants et au monde académique. Ils couvrent l'ensemble des sujets de travail de l'AFD : analyse économique, théorie économique, analyse des politiques publiques, sciences de l'ingénieur, sociologie, géographie et anthropologie. Une publication dans les Papiers de Recherche de l'AFD n'en exclut aucune autre.

Les opinions exprimées dans ce papier sont celles de son (ses) auteur(s) et ne reflètent pas nécessairement celles de l'AFD. Ce document est publié sous l'entière responsabilité de son (ses) auteur(s).

\section{Research Papers}

AFD Research Papers are intended to rapidly disseminate findings of ongoing work and mainly target researchers, students and the wider academic community. They cover the full range of AFD work, including: economic analysis, economic theory, policy analysis, engineering sciences, sociology, geography and anthropology. AFD Research Papers and other publications are not mutually exclusive.

The opinions expressed in this paper are those of the author(s) and do not necessarily reflect the position of AFD. It is therefore published under the sole responsibility of its author(s). 


\title{
Social Protection and Multidimensional Poverty: Lessons from Ethiopia, India and Peru
}

\author{
Liyousew G. Borga \\ Conchita D'Ambrosio \\ Department of Behavioural and Cognitive Sciences, \\ University of Luxembourg
}

\section{Résumé}

Cet article analyse l'impact de trois programmes de protection sociale à grande échelle sur la pauvreté multidimensionnelle en Éthiopie, en Inde et au Pérou. À l'aide des données en panel $\mathrm{du}$ projet Young Lives, nous montrons quels sont la tendance, les changements et l'évolution de la pauvreté multidimensionnelle pour les ménages participants au programme. Nous analysons aussi un certain nombre de stratégies pour produire des estimations qui traitent du placement non aléatoire du programme. Les résultats montrent qu'au cours de la décennie 2006-2016 des mesures de l'incidence et de l'intensité de la pauvreté multidimensionnelle ont diminué davantage pour les participants au programme que pour les non-participants dans tous les pays. Nous constatons un impact positif à court terme sur la formation d'actifs et d'élevage et sur certains indicateurs du bien-être. Dans les trois pays, ces effets positifs se maintiennent même à moyen et à long terme.

Mots-clés: Protection sociale, pauvreté multidimentionelle, PSNP; NREGS; Juntos; Young lives

\begin{abstract}
We investigate the impact of three large-scale socialprotection schemes in Ethiopia, India, and Peru on multidimensional poverty. Using data from the Young Lives cohort study, we show the trend, changes and evolution of multidimensional poverty for program participant households. We follow a number of strategies to produce estimates that deal with non-random program placement. Our findings show that both the incidence and intensity of multidimensional poverty declined in all thee countries over the period 2006 - 2016, more so for program participants than nonparticipants. We find positive short-term impact on asset formation, livestock holding, and some living standard indicators. In all three countries these positive impacts are sustained even in the medium and longerterm.
\end{abstract}

Keywords: Social protection; Multidimensional poverty; PSNP; NREGS; Juntos; Young lives

\section{Acknowledgements}

We acknowledge financial support from the Fonds National de la Recherche Luxembourg and the European Union (EU-AFD Research Facility on Inequalities). We thank Suman Seth, Martin Ravallion, Cecilia Poggi, Anda David, Carlos Soto Iguaran, Raphael Cottin, Andrew Clark and seminar participants at the 2018 ECINEQ, the 2018 DIAL, the 2018 EALE conferences, and the 2020 International Workshop on the Distributional Impact of Social Protection in Addis Ababa for their helpful comments. All errors are our own. The data used in this study come from Young Lives, a 15-year study of the nature of childhood poverty. Young Lives is funded by UK aid from the Department for International Development (DFID), with co-funding by the Netherlands Ministry of Foreign Affairs and Irish Aid. The views expressed herein must in no way be considered to reflect the official position of the European Union, AFD, Young Lives, the University of Oxford, DFID or other funders.

JEL Classification: D31, 132, I38, $\mathrm{H} 4$

Original version: English

Accepted: July 2020 


\section{Introduction}

Many developing countries in Africa, Asia, and Latin America have adopted social-protection schemes as a way to tackling extreme poverty, rising inequality, risk, and vulnerability. These socialprotection schemes, implemented through a system of transfers in cash or in kind, aim to reduce poverty in the long-term and help vulnerable households cope with economic shocks in the short-term. Social protection now forms part of a comprehensive global-development agenda. Target 1.3 (Goal 1) of the Sustainable Development Goals (SDGs) is to implement nationally-appropriate social-protection systems and measures for all, and achieve substantial coverage of the poor and the vulnerable by 2030 . In developing and transition countries, 2.5 billion people are covered by safety-net programs that include cash or in-kind transfers, social pensions, public works, and school-meal programs (World Bank, 2018).

Social-protection programs take on various designs, forms and sizes. Some aim to simply supplement consumption in hard times, while others attempt to address the underlying market failures that led to poverty and vulnerability. Provided that the poor are identified through proper targeting mechanisms, there are a number of rationales for governments to engage in redistributive activities.

Many countries have introduced targeted interventions that identify who is poor and then restrict transfers to those individuals. Conditional cash transfers (CCTs) provide cash support, generally to

\footnotetext{
'Throughout this paper we use the terms public works, workfare, and employment guarantee schemes interchangeably.
}

poor households, conditional on certain pre-specified behaviours on the part of the beneficiary households. CCTs have become the main form of intervention targeting vulnerable families in developing countries. Originating in Brazil and Mexico in the 1990s, they initially spread over Latin America before being adopted throughout the world. CCTs typically aim to reduce poverty and increase human capital by requiring beneficiaries to comply with certain requirements such as school attendance and health checkups. Tying cash transfers to human-capital investments in children has been argued to help break intergenerational-poverty transmission (Olivier de Sardan and Piccoli, 2017).

Recent years have also seen an increasing interest in using workfare (cash or food for work) programs as a safety net for the poor, while improving infrastructure to promote long-term growth. In the absence of formal credit and insurance markets, these public-works programs comprise an integral component of the social-protection strategy. ${ }^{1}$ Public-works programs are designed to have positive impacts via multiple channels: a direct benefit through the wage paid to those in the public-works projects; via the productive assets created, which are intended to benefit the community as a whole; and through the skills that are learned by participants, which are expected to boost their future employment opportunities.

Despite the wealth of interest from policy makers, donors, and researchers, there is a paucity of evidence regarding the distributional incidence of these programs, and very little is about their effects on 
multidimensional poverty (Seth and Tutor, 2019). Traditional "benefit incidence" analyses attempt to capture a program's distributional impact by the income gains to participants conditional on their pre-intervention income, where the income gain is the difference between household income with and without the program. These methods are however based on strong assumptions, provide only incomplete picture of welfare effects, and ignore general-equilibrium and indirect effects on the poor (see for example Jalan and Ravallion, 2003; Murgai et al., 2016).

Income poverty is only one way of assessing living standards: poverty is multifaceted, and well-being can also be measured in many other dimensions. Empirical work has shown that significant percentages of those who are multidimensionally deprived are not monetary poor, and vice versa (see for example Alkire and Jahan, 2018). As such, it is crucial to understand the poverty-reduction impact of socialprotection programs in a multidimensional framework. Such a multidimensional approach also provides an alternative way of addressing some of the known blind spots of monetary poverty measures, such as missing markets, problems in measuring consumption, and the distinctive difference between transient and chronic poverty.

There is, however, a dearth of evidence as to whether social-protection programs reduce multidimensional poverty. Furthermore, due to data limitations and the restrictions imposed by robust empirical estimation, we still know very little about the mediumand long-run effects of public works and conditional cash transfer programs on poverty and inequality.
This paper intends to fill some of the evidence gaps on social-protection and its effects on multidimensional poverty, using information from a cohort survey in Ethiopia, India, and Peru combined with information on participation in national social-protection schemes. We evaluate three large-scale socialprotection schemes - the Productive Safety Net Program (PSNP) in Ethiopia, the National Rural Employment Guarantee Act (NREGA) in India, and the Juntos conditional cashtransfer program in Peru. We aim to establish the success of these programs in protecting the basic levels of consumption among vulnerable households and facilitating investment in productive assets. We provide new cross-country evidence on the causal relationship between large scale redistributive policies and multidimensional poverty in both the short and medium runs, allowing us to draw relevant policy recommendations.

We start by asking whether socialprotection program participation are less poor and less vulnerable after the program than they were before, and whether any impact is transient or rather persists in the medium to longer-run. We use rich panel data from the Young Lives Survey, which follows children, and their families, over a span of fifteen years in all of the three countries that we analyze. The longitudinal nature of the data here allows us to compare the same household at different points in time to see how their lives and their communities evolve. We can also compare and contrast the efficacy of the two main types of targeted interventions: conditional cash transfers and publicwork programs. In order to identify causal effects, we exploit the staged roll-out of the program across districts in India, and construct counterfactual comparison 
groups based on the probability of being treated given observable covariates in Ethiopia and Peru.

Our paper adds to a growing literature attempting to document the effectiveness of poverty-alleviation programs. However, we differ in that we go beyond traditional money-metric poverty assessment and rather focus on multiple non-income based measures that are also key for improving the design and effectiveness of poverty-reduction policies. To our knowledge, this is the first paper to document the effects of multiple largescale social-protection programs using multidimensional poverty indicators in panel surveys that are conducted simultaneously in all of the countries concerned. We can thus evaluate the similarity of our results across different countries, and draw conclusions that are relevant for other similar countries. We follow UNDP (2010), Alkire et al. (2014), and Alkire and Jahan (2018) in our measurement of multidimensional poverty, and construct an indicator based on health, education and living standards dimensions.
We find that multidimensional poverty declined in all thee countries over the 2006 - 2016 period, with program participants benefiting the most: program participation led to a significant fall in multidimensional poverty incidence and intensity in all three countries, and particularly for initially severely-poor participant households. We also find a positive sustained impact on asset formation, livestock holding, and some living-standard indicators. The effects of the social programs mainly emanate from the direct income effect of benefits. The conditionalities attached to the Juntos CCT program also have a positive long-term impact on child schoolattendance and schooling.

The remainder of this paper proceeds as follows. Section 1 reviews the related literature, and Section 2 provides background information about the study countries and the three programs. Section 3 presents the data and summary statistics. We then outline the empirical strategy of the paper and present the results in Section $4 . \quad$ Last, Section 4.4 concludes. 


\section{Theoretical Framework and Existing Literature}

In recent years, the share of the world's population living below the global extreme poverty line ( $\$ 1.90$ of consumption per day) has declined dramatically (from $42 \%$ in 1981 to $10 \%$ in 2015 , according to the most-recent estimates). Poverty reduction has often come about via either economic growth or the intentional redistribution of resources to the poor. The largest reductions in extreme poverty worldwide in the past few decades have resulted from substantial economic growth in many emerging economies, particularly China and India (Page and Pande, 2018). However, we likely cannot rely on economic growth alone to eradicate poverty for two reasons: first, a substantial amount of poverty, and inequality, remains even in rapidly-growing countries; and second, rapid economic growth is often hard to produce and sustain (Hanna and Olken, 2018). The continued reduction of extreme poverty may well therefore also require targeted interventions to help the poorest households improve their standards of living (Sulaiman, 2016).

Hanna and Karlan (2017) identify four underlying motivations for the use of social safety-net programs: redistribution, missing insurance markets, household-bargaining constraints, and market failures that prevent asset accumulation. Redistributive transfers, where the neediest families according to some metric are identified and provided with cash transfers, are socially optimal from a utilitarian perspective, ensuring that households attain a minimum living standard. In addition, these transfers may have long-run growth impacts by providing households with sufficient capital to start new businesses or promoting increased agricultural investment.

Missing insurance markets and imperfect access to credit are also important. In the absence of these financial institutions, households smooth consumption by making long-term sacrifices, such as pulling children out of school (Hanna and Karlan, 2017). Behavioral constraints, such as present bias and difficulty in resisting immediate temptations, can produce under-saving and subsequently under-investment. Similarly, intrahousehold-bargaining issues can lead to suboptimal outcomes for the underpowered, who are often women and children (Hanna and Karlan, 2017).

Redistributive social policies thus play a potentially key role in helping poor families in developing countries. Social safety-net programs protect vulnerable households from the impacts of economic shocks, natural disasters, and other crises. An estimated $36 \%$ of the very poor escaped extreme poverty because of social safety nets, providing clear evidence that these make a substantial contribution to the global fight against poverty (World Bank, 2018).

While most social-protection initiatives have the common goal of reducing extreme poverty, the details of the interventions and their intended pathways out of extreme poverty differ (Sulaiman, 2016). The identification of effective social-protection programs is crucial. The first fundamental issue is the targeting of beneficiaries: depending on the government's priorities, this targeting can be based on geographic criteria, means-testing, self-targeting, or community-based methods (Hanna and Karlan, 2017). 


\subsection{Conditional Cash Transfers (CCTs)}

Conditional cash transfers are payments that are targeted to the poor and made conditional on certain behaviors by the recipient households. In most cases, CCTs make payments to poor households on the condition that those households invest in their children's human capital in certain pre-specified ways. CCTs have two clear objectives: providing poor households with a minimum level of consumption and encouraging the accumulation of human capital to tackle the intergenerational transmission of poverty (Fiszbein and Schady, 2009).

There are three causal mechanisms via which CCTs may affect the household economic situation. First, these programs provide income that enables liquidity constrained poor households to undertake human capital investments (the "income effect"). Second, the conditions attached to the transfer increase the opportunity costs of not taking children to health clinics or not sending them to school (the "substitution effect"). Last, in cases where mothers are targeted as transfer recipients, due to the widespread belief that mothers' preferences are more closely aligned than the fathers' with children's interests, these transfers may affect intra-household resource allocation (the "distribution effect") (Kabeer and Waddington, 2015).

Recent CCT evaluations have concluded that, on the whole, they have positive short-term impacts on school enrollment, attendance and health outcomes for children covered by schooling-related conditions. Cash transfer programmes have generally been well-targeted to poor households, have raised consumption levels, and have reduced poverty - by a substantial amount in some countries (Fiszbein and Schady, 2009). These evaluations have also underlined substantial variation in the size of those impacts between countries, and across different program characteristics and target populations (Fiszbein and Schady, 2009; Saavedra et al., 2012).

Despite this evident success, CCTs have been criticized in a number of ways. First, some of the neediest households may find compliance with the associated conditions too costly, thereby excluding some of targeted population. Second, the households that do choose to participate may incur costly distortions in their own behavior for the sake of a short-run financial gain. In addition, CCTs cannot address the elderly poor, childless households, or households whose children are outside the age range covered by the CСT (Fiszbein and Schady, 2009).

Another commonly-cited problem with CCTs is the gap between the model and local realities. Qualitative evidence emphasizes the multiple challenges faced by CCTs, such as extra-official conditionalities, elite capture, or participants' failure to comply with the instructions (Olivier de Sardan and Piccoli, 2017; Cookson, 2015). In particular to Juntos, Cookson (2015) finds qualitative evidence of extra-official activities required of Juntos recipients such as having hospital births, participating in political parades, cooking for the State-run school meal program, and participating in cultural and micro-productive projects. According to Olivier de Sardan and Piccoli (2017), these extra conditionalities arise on the periphery of public policies and are neither outside the system nor truly official. They 
act as "tolerated instruments" for the purpose of satisfying policy indicators (for example hospital births, vaccinations) and as stopgap measures for the under-financing of public institutions (for example school meals).

While many CCT evaluations find positive short-run impacts on poverty alleviation, health and nutrition, particularly for young children, and better school outcomes for older children, there is much less work on whether these short-term gains translate into sustained longer-run benefits. In addition, most evaluation has not looked at the multidimensional aspect of poverty. After two decades of experience with CCTs, there is a growing need, and the potential, to investigate the longer-run effects of these programs using multidimensional well-being indicators (Molina Millan et al., 2016).

\subsection{Public-Works Programs}

Public-works programs are public interventions that provide employment to poor households and individuals at relatively low wages (Gehrke and Hartwig, 2018). There are two primary goals of most of these workfare programs. They help reduce poverty by transferring income to the poor and vulnerable, while the work carried out by the program participants contributes to the creation of public assets (such as better roads), which may benefit the broader community and help development in the targeted regions (Gehrke and Hartwig, 2018; Alderman and Yemtsov, 2014).

The conceptual framework in Gehrke and Hartwig (2018) sets out four mechanisms through which public-works programs may bring about positive outcomes. First, the programs provide employment on demand and the wage paid to workers may have a more or less effective insurance function, thereby improving individual risk management and increasing productive investments. Second, employment creation affects the equilibrium in the labor market. If the program wage is set too high relative to market wages, the program will put upward pressure on private-sector wages for unskilled workers, reduce the number of private-sector jobs, attract workers who are not poor, and may induce excessive risk-taking among workers. Third, some programs include an implicit or explicit training component, through which participants may improve their employability or boost the chances of earning income from self-employment. Last, as productive assets are created that are intended to benefit the wider community, market access could be improved through road construction which in turn increases trade and production.

There is a growing literature that attempts to document the different effects of public-works programs, such as the general equilibrium price and wage effects (Cunha et al., 2019; Berg et al., 2018), labor-market responses (Afridi et al., 2016; Imbert and Papp, 2015; Zimmermann, 2014), and the effects on risk-sharing networks (Angelucci and De Giorgi, 2009). Some other contributions have looked at the effects of social-protection programs on household consumption (Bose, 2017) and household management of production risks (Gehrke, 2017).

The empirical evidence on the effectiveness of these programs is mixed. Some work has 
shown that workfare programs have been successful in alleviating the negative effects of higher food prices, economic downturns and other crises (Bertrand et al., 2017; Galasso and Ravallion, 2004). However, these programs are demanding from an administrative perspective and comparatively expensive to run (Gehrke and Hartwig, 2018). The World Bank's Atlas of Social Protection: Indicators of Resilience and Equity (ASPIRE) database shows that public-works programs have an average Benefit-Cost-Ratio (BCR), defined as the reduction in the poverty gap obtained for each dollar spent in the program, of 0.31. The average BCR for Conditional Cash Transfer programs is 0.42 (World Bank, 2018). There is also some argument that participants' welfare losses from forgone income maybe considerably higher in public-works programs than in other poverty-reduction programs (Murgai et al., 2016).

Social-protection programs may have both intended and unintended consequences. Although empirical analyses typically find that public-works programs in developing countries attain their target group of poor households (see Zimmermann, 2014, for a review), some have also underlined the unintended consequences of these programs, notably on human-capital accumulation (Shah and Steinberg, 2019; Li and Sekhri, 2013).

A number of impact evaluations have considered the effects of the three social safety-net programs that we analyze here. Imbert and Papp (2015) estimate the effect of NREGA on private employment and wages, and show that public-sector hiring crowded out private-sector work and increased private-sector wages. Gehrke (2017) find that households with access to the program are more likely to take riskier agricultural investment decisions. Evidence from Andhra Pradesh in India suggests that mothers' participation in the labor force increases their children's time spent in school and leads to better grade progression (Afridi et al., 2016).

Andersen et al. (2015) use the Young Lives survey data to estimate the link between participation in Peru's Juntos CCT and anthropometry, language development, and school achievement among young children: they find that participation was associated with better height-for-age growth among boys. Similarly, using the same sample of children, Sánchez et al. (2020) highlight that exposure to Juntos led to improved nutritional status and cognitive achievement, both of which improvements were larger for children initially exposed to the program during the first four years of their lives. Dasgupta (2017) also uses Young Lives data, and find a significant positive causal effect of NREGA in mitigating the effects of negative early-life rainfall shocks on children's long-run health outcomes.

Berhane et al. (2014) look at the impact of the duration of participation in Ethiopia's PSNP, and show that five years' participation raises livestock holdings as compared to one year's participation. Gilligan et al. (2009) also estimate the impact of PSNP on household welfare, asset ownership, and agricultural and economic activity in 2006, after the first year of the project, and find only weak impacts of PSNP. Similarly, Andersson et al. (2011) find some evidence that PSNP participation increased the number of trees planted, but with no increase in livestock holdings. A review by Beierl and Grimm (2018) concludes that none of the research conducted on PSNP provides convincing and robust empirical evidence that the program can sustainably boost participants' total income, expenditure or (non-food) consumption. 
Our paper complements this rich body of work. The literature is only scant regarding the evaluation of the effect of social-protection schemes on multidimensional poverty. In addition, current knowledge about program impacts is mostly restricted to short-run outcomes. We will below evaluate the trend, changes and evolution of the well-being of program-participant households in the medium and longer-term using multidimensional poverty measures.

\section{Study Context}

\subsection{Ethiopia: The Productive Safety Net Program (PSNP)}

The Productive Safety Net Program (PSNP) is a public program introduced in Ethiopia in 2005 by the government and a consortium of donors as a safety net, targeting transfers to poor households through either public works or direct support. The aim is to enable households smooth consumption without the need to sell productive assets in lean periods. The publicworks segment of the program pays selected beneficiaries for their work on labor-intensive projects designed to build community assets. By reducing seasonal liquidity constraints, it is also intended to stimulate investments (Andersson et al., 2011; Gilligan et al., 2009).

The selection of the beneficiaries for both the public-works and direct-support components of the safety-net program relies on a mix of administrative criteria and community input. When the program began in 2005, historical data on food-aid allocations were used to select beneficiary districts (woredas). Within the woredas, local administrators selected the chronically food-insecure kebeles (the lowest administrative unit), splitting up the woredas "PSNP quota" among these areas (Berhane et al., 2014). PSNP eligibility at the household-level was determined by the household's chronic history of food need, the level of the food gap or unmet need, and the household labor available for work. Communities selected beneficiaries in collaboration with the kebeles, refining the selection based on household assets (landholdings), and income from non-agricultural activities and alternative sources of employment (Gilligan et al., 2009; Berhane et al., 2014).

\subsection{India: The National Rural Employment Guarantee Act (NREGA)}

The National Rural Employment Guarantee Act (NREGA) was passed in 2005, and the scheme began to roll-out in February 2006. The Act entitles every household in rural India to 100 days of work per year at a State-level minimum wage to rural households willing to supply manual labor to local public works. To obtain work on a project, adult applicants lodge an application for a job card at their local Gram Panchayat (the lowest government administrative unit). After verification, a job card is issued and workers can start applying for work. If an applicant is not assigned to a project, they are eligible for unemployment compensation. Applicants 
cannot choose the project they work on (Shah and Steinberg, 2019).

The act was gradually introduced throughout India, starting with 200 of the poorest districts in February 2006, extending to 130 districts in April 2007, and to the remainder of rural India in April 2008. In the Andhra Pradesh region from which our data comes, four of the Young Lives sample districts (comprising $66 \%$ of the sample) were covered by the NREGA in the first phase of implementation in 2006 (Dasgupta, 2017).

\subsection{Peru: Juntos}

The conditional cash transfer program Juntos was established in 2005, targeting poor families mainly in rural Peru. Its geographical coverage has increased gradually over time, after initially serving 70 districts in the Southern highlands, to include other areas of the highlands and the Amazonian jungle. Juntos eligibility is based on a three-stage selection process: selection of eligible districts, selection of eligible households within those districts, and community-level validation. Exposure to violence due to guerrilla activity, poverty, unmet basic needs, and the level of child malnutrition are the main variables considered in the district selection. Household eligibility within districts was determined by a proxy means test formula based on census data. ${ }^{2}$ In addition, only households with children under the age of 14 or at least one pregnant woman were selected. The final stage is community-level validation that was carried out by community members, local authorities and representatives of the Ministries of Education and Health. Beneficiary households received transfers of 100 Soles ( $~ 30$ US Dollars) each month regardless of the household composition, representing about 15\% of beneficiary household spending (Andersen et al., 2015; Perova and Vakis, 2012).

The conditions for transfers under Juntos depend on the age and eligibility of the participant. Members of households with children under five years of age as well as households with a pregnant or lactating woman are required to attend regular health-care visits. Children aged between 6 and 14 years who had not completed primary school are required to attend school on at least $85 \%$ of school days (Andersen et al., 2015).

\section{Data}

The data we use for our analysis come from the Young Lives Project, which tracks the lives of children in four countries: Ethiopia, India (in the states of Andhra Pradesh and Telangana), Peru and Vietnam over a 15-year period. In each of the four countries, Young Lives surveys follow 3,000 children in two cohorts: the younger cohort consists of 2,000 children who were born between January 2001 and May 2002, and the older cohort approximately 1,000 children

\footnotetext{
${ }^{2}$ The term "proxy means test" is used to describe a situation where information on household or individual characteristics correlated with welfare levels is used in a formal algorithm to proxy household income, welfare or need (Grosh and Baker, 1995).
} 
from each country who were born in 1994-95. Five survey waves are currently available: the baseline round in 2002 and four follow-up waves in 2006, 2009, 2013 and 2016.

One of the advantages of the Young lives survey is that it includes a wide range of well-being indicators, including asset holdings, consumption expenditure, physical and emotional health, nutrition, education and material wealth, as well as child-development indicators. This breadth of well-being indicators is seldom found in national representative samples, which typically narrow their focus towards individuals' ability to access basic services. The longitudinal nature of the data allows us to document the evolution of poverty over time.

\subsection{Survey Design and Sampling}

Young Lives' respondents were selected from 20 sentinel sites that were specifically designed in each country. ${ }^{3}$ The concept of a sentinel site comes from health surveillance studies and is a form of purposive sampling where the site (or "cluster" in sampling language) is deemed to represent a certain type of population, and is expected to show typical trends affecting those people or areas. The districts (administrative divisions in each country) were selected first, and then 20 sentinel sites were identified within each district according to an agreed set of criteria. Last, 100 households with a child born in 2001-02 and 50 households with a child born in 1994-95 were randomly selected in each sentinel sites.

In Ethiopia, five out of the country's nine States and two city administrations were selected. The five regions account for $96 \%$ of the national population. Between three and five woredas (districts) were selected in each region, with a balanced representation of poverty levels, urban and rural areas, and a variety of urban-site types (capital city, intermediate city, and small urban areas). Among the woredas with food-deficit status in each region, the three with the highest proportion and that with the lowest proportion were selected. Even though Young Lives is not intended to be a nationally-representative survey, compared to the Demographic and Health Survey (DHS) or the Welfare Monitoring Survey (WMS), the sample includes a wide range of living standards, which turns out to be similar to that found in the Ethiopian population as a whole (Outes-Leon and Sanchez, 2008; Outes-Leon and Dercon, 2008).

The sampling strategy followed by Young Lives in India (Andhra Pradesh) was semi-purposive, and similar to that in Ethiopia. The selection process of districts for the survey ensured that all geographical regions were surveyed, as too were the poor and non-poor districts of each region (based on economic, human development and infrastructure indicators). Undivided Andhra Pradesh ${ }^{4}$ had three distinct agro-climatic regions: Coastal Andhra, Rayalaseema, and Telangana. The sampling scheme adopted was designed to identify regional variations with the following priorities: a uniform distribution of sample districts across the three regions to ensure full regional representation; the selection of one poor and one non-poor district in each region, based

\footnotetext{
${ }^{3}$ See the survey documentation at https://www.younglives.org.uk/ for further details.

${ }^{4}$ The State of Andhra Pradesh was divided into the States of Andhra Pradesh and Telangana in 2013.
} 
on a ranking of development indicators; and considering issues that might affect childhood poverty in poor districts and mandals (Gehrke, 2017; Kumra, 2008).

In Peru, somewhat differently from Ethiopia and India, the sampling of clusters was random (in the other countries it was semi-random/semi-purposive, as described above). The district level was used as the sample frame. The most recent poverty map of all districts in Peru in 2001 was used to select the 20 clusters. Factors such as infant mortality, housing, schooling, road networks and access to services determined the ranking of districts. To attain the aim of over-sampling poor areas, the highest ranking $5 \%$ of districts (all located in Lima) were excluded. The resulting districts were designed to cover rural, urban, peri-urban, coastal, mountain and Amazon areas. Another consideration during sampling of districts was logistical feasibility. Following the selection of districts, a random population center (i.e. a village or hamlet) was chosen within the district. A comparison to the DHS from 2000 (the year closest to the first wave of Young Lives in 2002), indicates that the Young Lives sample covers the diversity of children and families in Peru (Escobal and Flores, 2008).

\subsection{Variable Definition}

\section{Multidimensional Poverty Indicators}

We will analyze multidimensional poverty using the well-being indicators and the method outlined in the United Nation's multiple Human Development Reports since 2010 (UNDP, 2010; Alkire and Jahan, 2018). The list of indicators, as well as the deprivation and poverty cutoffs, are consistent with those in the Human Development Reports for the three countries we consider. These indicators were selected after a thorough consultation process involving experts in all three dimensions, and building on recent advances in theory and data. The relevance of these dimensions and indicators is well-documented in the literature (see for instance, Alkire and Jahan, 2018; Alkire and Seth, 2015; Alkire and Foster, 2011). They aim to assess multidimensional poverty levels in specific countries or regions using the the most-relevant and locally-feasible indicators (Alkire and Jahan, 2018).

The Young Lives survey includes detailed information regarding the household's access to services, living standards, and ownership of consumer durables, land and livestock. ${ }^{5}$ We use information on number of bedrooms per person, and whether or not the quality of main materials of dwelling (walls, roof and floor) satisfy basic norms of quality as measures of housing quality. The household's ability to meet functional requirements of sound shelter is given by access to electricity, safe drinking water, a safely-managed sanitation service, and adequate fuel for cooking. The household's ownership of common household items is summarized by a consumer-durable index, which is the average of a set of dummy variables for the household member owning at least one of each consumer durable in working condition and that could be sold by the household. ${ }^{6}$ Education is measured by the number of completed years of schooling for adults and school attendance for children. We use the anthropometric information in the dataset to construct health and nutrition

\footnotetext{
${ }^{5}$ Annual household income and its different sources are recorded only in two of the five waves of the data.

${ }^{6} \mathrm{~A}$ summary wealth index is estimated from three sub-indices (all of which have equal weights) - the housingquality, access to services and consumer-durable indices.
} 
indicators.

\section{Public programs}

Households in the sample were asked about their participation status in a number of countryspecific public programs, including participation duration, type of support and the benefits received.

\section{Household characteristics}

We have information on the characteristics of the household head (age, gender and education), the number of household members by sex and age group, and household size in the dataset. Other time-invariant characteristics such as ethnicity, religion, and language are also available.

\section{Shocks and adverse events}

The data also records detailed information on events that have negatively affected the household's economic situation, as reported by the respondent. These events include natural disasters, changes in economic conditions, changes in regulation, crime (e.g. theft) and other disasters (both natural and man-made). All shock-related variables are binary (for the the shock having been reported).

\subsection{Summary Statistics}

We present the summary statistics of the main variables and controls used in the paper in Tables A.l-A.3 in Appendix A. We split the sample by participation status (program participants vs. non-participants) as well as the pre- and post-program periods. We use the wave 2 survey (2006) for the pre-program period and averaged the outcomes in waves 3-5 for the post-program period.

Respondents were asked to report their month and year of Juntos initiation in the data. Juntos officially started in 2005 , and about $2 \%$ of our sample started receiving transfers in 2006. Hence, in our pre-post program analysis we exclude these households due to lack of sufficient baseline data. Similarly Gilligan et al. (2009) and Porter and Goyal (2016) show that PSNP transfers were delayed during the first year of implementation of the PSNP (2005/6), and impact was not experienced until after wave 2 of our data was collected, justifying the use of 2006 as our baseline.

We find similar patterns in all the three countries. On average, program-participant households have heads with fewer years of education, larger household size, and less access to basic services; participant households are also relatively poor, with lower wealth-index figures, and are more susceptible to drought-induced shocks: the social-security programs thus seem to reach their target group of poor households. This is in line with the findings from the contributions cited above. Although some fraction of the non-poor often benefit as well, targeting does seem to be fairly successful in most 
public-works programs, and to work better in this respect than a number of traditional cash-transfer programs for the poor (Zimmermann, 2014).

\section{Social Protection and Multidimensional Poverty}

\subsection{Measuring Multidimensional Poverty}

The measurement of poverty remains an area of active debate. Traditional money-metric poverty assessment, which mainly uses income or consumption-based measures, is deemed incomplete as it disregards non-income based aspects of life that are equally vital for improving the design and effectiveness of poverty-reduction policies. Many researchers prefer an approach that proposes a broad, rich, and multidimensional view of human well-being, paying attention to the links between the economic, social, and political dimensions of life.

The calculation of multidimensional poverty requires the selection of the relevant dimensions and their corresponding indicators, the aggregation of the indicators within and across dimensions, and the choice of cut-off points to distinguish the poor from the non-poor. The empirical framework in this paper follows the counting approach of measuring multidimensional poverty (Atkinson, 2003), as implemented by Alkire and Foster (2011) (henceforth AF). Building on the Foster-Greer-Thorbecke poverty measures, the AF proposal involves counting the different types of deprivation that individuals experience, such as a lack of education or employment, and poor health or living standards. These deprivation profiles are analyzed to identify who is poor, and then used to construct a multidimensional poverty index.

The basic definitions and notation for multidimensional poverty using the AF method are as follows. Suppose we have $n$ individuals in the population, and let $d \geq 2$ be the number of dimensions under consideration. Let $Y=\left[Y_{i j}\right]$ denote the $n \times D$ matrix of well-being outcomes, where the typical entry $Y_{i j}$ is the achievement of the individual $i=1,2, \ldots, n$ in dimension $j=1,2, \ldots, D$. Let $z_{j}$ denote the cut-off below which a person is considered to be deprived in dimension $j$. Expressing the data in terms of deprivations rather than achievements, for any given $y$, let $g_{i j}^{0}=1$ when $Y_{i j}<z_{j}$, and $g_{i j}^{0}=0$ otherwise. From the matrix $g^{0}$ we can construct a column vector $c$ of deprivation counts, whose $i^{\text {th }}$ entry $c_{i}=\left|g_{i}^{0}\right|$ represents the number of deprivations suffered by person $i$. The deprivation of each person may also be weighted by the indicator's weight, given by $w_{j}$ with $\sum_{j} w_{j}=1$. This produces a deprivation score for each individual, defined as the weighted sum of deprivations $c_{i}=\sum_{j=1}^{d} w_{j} g_{i j}^{0}$ (Alkire and Foster, 2011).

In order to identify who is poor and who is not, Alkire and Foster (2011) propose the intermediate identification method, such that individual $i$ is poor when the number of dimensions in which $i$ is deprived is at least $k$, where $k$ is chosen by the researcher.

Different indices are used in the last step to measure poverty: (i) the Headcount ratio 
(incidence of poverty), $H$; (ii) the Average Poverty Gap (intensity of poverty), $A$; and (iii) the Adjusted Headcount ratio, MPI.

The headcount ratio $(H)$ measures the incidence of poverty, or the proportion of people (within a given population) who experience multiple deprivation. It is calculated by dividing the total number of households who are identified as poor $(q)$ by the total population $(n)$ : $H=1 / n \sum_{i=1}^{n} q_{i}$. The average poverty gap $(A)$ measures the intensity of their deprivation the average proportion of (weighted) deprivation they experience. For the multidimensionally-poor only, (those with a deprivation score $c$ greater than or equal to the cutoff), the deprivation scores are summed and divided by the total number of multidimensionally-poor individuals $\left(A=\sum_{i=1}^{q} c_{i} / q\right)$. The Adjusted Headcount ratio (MPI) combines the information on the incidence and intensity of multidimensional poverty among the poor $(M P I=H \cdot A)$. This represents the share of the population that is multidimensionally-poor adjusted by the intensity of the deprivation they suffer. This is the index that we use here.

\subsection{Descriptive Evidence}

We measure the MPI using 10 indicators that are grouped into three dimensions: Education, Health, and Standard of Living. The education dimension consists of years of schooling and school attendance; health includes nutrition and child mortality; and standard of living is made up of access to electricity, sanitation, water, flooring material, cooking fuel, and asset ownership. Table A.4 in Appendix A summarizes the dimensions, the cutoff criteria and the weights assigned to the 10 indicators that we use.

To identify the multidimensionally-poor, the deprivation scores for each indicator are summed to obtain the household deprivation score. We consider three separate cutoffs: $20 \%, 33 \%$ and $50 \%$ of the weighted indicator score. As in Alkire and Seth (2015), a household is poor if its deprivation score $c_{i}$ is $1 / 3(33 \%)$ or more. Individuals with a deprivation score of $1 / 5$ (20\%) or higher, but under $1 / 3$, are considered to be vulnerable to multidimensional poverty; those with a deprivation score of $1 / 2(50 \%)$ or higher are considered to be in severe multidimensional poverty.

Our descriptive results appear in Tables 1 and 2 below. Table 1 sets out the trends in multidimensional poverty in Ethiopia, India, and Peru by program-participation status over the four waves of the survey. Table 2 in addition shows the two MPI components ( $H$ and $A$ ), using $k=33 \%$. Multidimensional poverty declined steadily between 2006 and 2016 in all three countries, and this fall in the $M P I$ is robust to the different deprivation cutoffs. Although all three countries experienced poverty reduction, the size of this drop varies both across countries and by participation in the social-protection programs.

The largest fall in multidimensional poverty was experienced by Juntos participants in Peru, where the MPI declined from 0.57 in 2006 to 0.16 in 2016. Decomposing this figure into the incidence and intensity of poverty, the poverty incidence in these households fell by 56 percentage points over the 10-year period, with a drop in poverty intensity of 18 percentage points. There is also a sizable drop in the $M P I$ and its components for both PSNP and NREGA 
participants in Ethiopia and India. The reduction in multidimensional poverty for households not covered by the programs is smaller in all three countries. Similarly, the proportion of multidimensionally-poor that are in severe poverty shows a marked decline over the decade. Overall, participation in social safety-net programs is associated with a greater decline in all of the multidimensional-poverty indicators.

The bulk of the fall in poverty occurred between the second and third waves (2006-2009), a period that coincided with the launching of the social safety-net programs in these countries. There was a further decline in multidimensional poverty between 2009 and 2013, after which poverty levels have plateaued. The intensity of poverty remains high in all countries and waves, with the average multidimensionally-poor individual being deprived in at least $40 \%$ of the weighted indicators.

We have also calculated the contribution of each dimension to multidimensional poverty. The full results appear in Table A.5 in Appendix A. This decomposition reveals useful information on a country's deprivation structure, and can help with policy-targeting. Deprivation in the education dimension accounts for over half of multidimensional poverty in Ethiopia and Peru, with a figure of two-thirds in India. Deprivation in living conditions is the second most important dimension for overall poverty. In line with the initial results from our descriptive statistics, and underlining our findings regarding targeting, program participants in all three countries are more deprived in living-condition indicators than are non-participants. 
Table 1: The Multidimensional Poverty Index (MPI)

\begin{tabular}{|c|c|c|c|c|c|c|c|c|}
\hline & \multicolumn{2}{|c|}{2006} & \multicolumn{2}{|r|}{2009} & \multicolumn{2}{|r|}{2013} & \multicolumn{2}{|r|}{2016} \\
\hline & Part. & Non-Part. & Part. & Non-Part. & Part. & Non-Part. & Part. & Non-Part. \\
\hline \multicolumn{9}{|c|}{ Ethiopia } \\
\hline$k=20 \%$ & 0.57 & 0.44 & 0.45 & 0.33 & 0.41 & 0.28 & 0.39 & 0.29 \\
\hline$k=33 \%$ & 0.56 & 0.40 & 0.42 & 0.29 & 0.37 & 0.22 & 0.36 & 0.24 \\
\hline$k=50 \%$ & 0.48 & 0.29 & 0.24 & 0.18 & 0.19 & 0.11 & 0.19 & 0.10 \\
\hline \multicolumn{9}{|l|}{ India } \\
\hline$k=20 \%$ & 0.35 & 0.32 & 0.24 & 0.22 & 0.20 & 0.19 & 0.20 & 0.18 \\
\hline$k=33 \%$ & 0.31 & 0.27 & 0.18 & 0.16 & 0.12 & 0.12 & 0.15 & 0.14 \\
\hline$k=50 \%$ & 0.19 & 0.16 & 0.07 & 0.07 & 0.02 & 0.04 & 0.03 & 0.03 \\
\hline \multicolumn{9}{|l|}{ Peru } \\
\hline$k=20 \%$ & 0.58 & 0.26 & 0.35 & 0.11 & 0.29 & 0.09 & 0.24 & 0.08 \\
\hline$k=33 \%$ & 0.57 & 0.21 & 0.28 & 0.07 & 0.21 & 0.06 & 0.16 & 0.05 \\
\hline$k=50 \%$ & 0.51 & 0.14 & 0.13 & 0.03 & 0.07 & 0.02 & 0.06 & 0.01 \\
\hline
\end{tabular}

Number of observations: Ethiopia $N=2892$ (805 PSNP participants and 2087 non-participants); India $N=2944$ (1738 NREGA participants, 1206 non-participants); Peru $N=2766$ (427 Juntos participants, 2339 non-participants). The columns labeled "Part." and "Non-Part" denote program participants and non-participants respectively. Program implementation in all three countries started after the 2006 survey. The rows labeled $k=20 \%, 33 \%, 50 \%$ show the MPI figure using the respective deprivation cutoff. 
Table 2: The Incidence and Intensity of Multidimensional Poverty (MPI)

\begin{tabular}{|c|c|c|c|c|c|c|c|c|}
\hline & \multicolumn{2}{|c|}{2006} & \multicolumn{2}{|r|}{2009} & \multicolumn{2}{|r|}{2013} & \multicolumn{2}{|r|}{2016} \\
\hline & Part. & Non-Part. & Part. & Non-Part. & Part. & Non-Part. & Part. & Non-Part. \\
\hline \multicolumn{9}{|l|}{ Ethiopia } \\
\hline Incidence & 97.2 & 74.7 & 85.9 & 59.2 & 80.1 & 49.6 & 80.2 & 55.8 \\
\hline Intensity & 57.9 & 53.0 & 48.4 & 48.4 & 46.1 & 45.0 & 44.6 & 43.7 \\
\hline \multicolumn{9}{|l|}{ India } \\
\hline Incidence & 62.4 & 53.3 & 39.8 & 34.0 & 27.9 & 26.5 & 36.9 & 32.7 \\
\hline Intensity & 49.3 & 50.6 & 44.6 & 45.7 & 42.1 & 44.0 & 41.0 & 41.5 \\
\hline \multicolumn{9}{|l|}{ Peru } \\
\hline Incidence & 94.4 & 42.6 & 62.5 & 16.5 & 48.7 & 15.1 & 38.8 & 11.6 \\
\hline Intensity & 60.5 & 50.1 & 45.2 & 43.8 & 43.2 & 41.8 & 42.4 & 40.7 \\
\hline
\end{tabular}

We next ask which deprivation indicators fell the most. Table 3 reveals a statistically significant reduction in multidimensional poverty between 2006 and 2009 in all three countries. The falls are the largest for the school attendance (34\%) and access to improved sanitation (23\%) indicators in Ethiopia, followed by the other standard-of-living and nutrition indicators, each of which dropped by between $5 \%$ and $12 \%$. In India, deprivation in school attendance fell by $30 \%$, while deprivation in access to improved cooking fuel and sanitation dropped by $17 \%$ and $15 \%$ respectively. In Peru, it is again school-attendance deprivation that fell the most, by $42 \%$, with significant reductions in most other indicators, all of which declined by over 9\%. Tables A.6 - A.8 in Appendix A list the percentage of individuals who are poor and deprived for each indicator (censored headcount) and the percentage contribution of each indicator to the MPI in the three countries. 
Table 3: Dimensional Decomposition and the Contribution of the MPI Indicators, by Participation Status

\begin{tabular}{|c|c|c|c|c|c|c|c|c|c|}
\hline & \multicolumn{3}{|c|}{ All } & \multicolumn{3}{|c|}{ Participants } & \multicolumn{3}{|c|}{ Non-participants } \\
\hline & 2006 & 2009 & Difference & 2006 & 2009 & Difference & 2006 & 2009 & Difference \\
\hline \multicolumn{10}{|c|}{ Ethiopia: PSNP } \\
\hline Electricity & $55.4 \%$ & $47.2 \%$ & $-8.2^{* * *}$ & $79.6 \%$ & $69.2 \%$ & $-10.3^{* * *}$ & $45.9 \%$ & $38.4 \%$ & $-7.5^{* * *}$ \\
\hline Sanitation & $51.9 \%$ & $28.8 \%$ & $-23.1^{* * *}$ & $68.0 \%$ & $31.7 \%$ & $-36.3^{* * *}$ & $45.5 \%$ & $27.6 \%$ & $-17.9 * * *$ \\
\hline Water & $45.2 \%$ & $40.0 \%$ & $-5.3^{* * *}$ & $49.0 \%$ & $52.7 \%$ & 3.7 & $43.8 \%$ & $34.9 \%$ & $-8.9^{* * *}$ \\
\hline Housing & $62.2 \%$ & $53.5 \%$ & $-8.7^{* * *}$ & $74.9 \%$ & $68.0 \%$ & $-6.9 * * *$ & $57.2 \%$ & $47.7 \%$ & $-9.4^{* * *}$ \\
\hline Cooking fuel & $78.4 \%$ & $66.0 \%$ & $-12.4^{* * *}$ & $97.0 \%$ & $85.9 \%$ & $-11.1^{* * *}$ & $71.0 \%$ & $58.1 \%$ & $-13.0 * * *$ \\
\hline Assets & $20.2 \%$ & $13.6 \%$ & $-6.6 * * *$ & $43.2 \%$ & $30.5 \%$ & $-12.7^{* * *}$ & $11.0 \%$ & $6.8 \%$ & $-4.2^{* * *}$ \\
\hline Attendance & $60.1 \%$ & $25.6 \%$ & $-34.5^{* * *}$ & $68.5 \%$ & $24.8 \%$ & $-43.7^{* * *}$ & $56.8 \%$ & $25.9 \%$ & $-30.9 * * *$ \\
\hline Schooling & $70.9 \%$ & $63.2 \%$ & $-7.7^{* * *}$ & $93.4 \%$ & $84.6 \%$ & $-8.9^{* * *}$ & $62.0 \%$ & $54.7 \%$ & $-7.3^{* * *}$ \\
\hline Nutrition & $30.3 \%$ & $22.3 \%$ & $-8.0 * * *$ & $38.6 \%$ & $27.7 \%$ & $-10.8 * * *$ & $27.1 \%$ & $20.2 \%$ & $-6.9 * * *$ \\
\hline \multicolumn{10}{|c|}{ India: NREGA } \\
\hline Electricity & $9.7 \%$ & $2.6 \%$ & $-7.1^{* * *}$ & $13.5 \%$ & $3.7 \%$ & $-9.8 * * *$ & $4.1 \%$ & $1.0 \%$ & $-3.1^{* * *}$ \\
\hline Sanitation & $49.0 \%$ & $34.0 \%$ & $-15 . .^{* * *}$ & $69.6 \%$ & $49.3 \%$ & $-20.3^{* * *}$ & $18.5 \%$ & $11.3 \%$ & $-7.2^{* * *}$ \\
\hline Water & $4.4 \%$ & $2.4 \%$ & $-2.0 * * *$ & $6.8 \%$ & $3.7 \%$ & $-3.1^{* * *}$ & $0.9 \%$ & $0.4 \%$ & -0.4 \\
\hline Housing & $25.5 \%$ & $17.2 \%$ & $-8.4^{* * *}$ & $36.0 \%$ & $25.1 \%$ & $-10.9 * * *$ & $9.9 \%$ & $5.4 \%$ & $-4.5^{* * *}$ \\
\hline Cooking fuel & $52.4 \%$ & $35.2 \%$ & $-17.1^{* * *}$ & $72.9 \%$ & $50.7 \%$ & $-22.2^{* * *}$ & $21.8 \%$ & $12.3 \%$ & $-9.5^{* * *}$ \\
\hline Assets & $22.3 \%$ & $7.8 \%$ & $-14.5^{* * *}$ & $32.6 \%$ & $11.2 \%$ & $-21.4^{* * *}$ & $7.1 \%$ & $2.8 \%$ & $-4.3^{* * *}$ \\
\hline Attendance & $40.5 \%$ & $10.0 \%$ & $-30.4^{* * *}$ & $47.1 \%$ & $12.2 \%$ & $-35.0^{* * *}$ & $30.6 \%$ & $6.9 \%$ & $-23.6 * * *$ \\
\hline Schooling & $49.9 \%$ & $35.3 \%$ & $-14.5^{* * *}$ & $64.9 \%$ & $48.7 \%$ & $-16.2^{* * *}$ & $27.5 \%$ & $15.5 \%$ & $-12.0^{* * *}$ \\
\hline Nutrition & $31.8 \%$ & $23.3 \%$ & $-8.5^{* * *}$ & $39.0 \%$ & $31.8 \%$ & $-7.2^{* * *}$ & $21.0 \%$ & $10.6 \%$ & $-10.4^{* * *}$ \\
\hline \multicolumn{10}{|c|}{ Peru: Juntos } \\
\hline Electricity & $21.7 \%$ & $9.7 \%$ & $-12.0 * * *$ & $51.5 \%$ & $26.5 \%$ & $-25.0 * * *$ & $16.1 \%$ & $6.3 \%$ & $-9.7^{* * *}$ \\
\hline Sanitation & $13.1 \%$ & $4.4 \%$ & $-8.7^{* * *}$ & $31.3 \%$ & $9.1 \%$ & $-22.2^{* * *}$ & $9.6 \%$ & $3.5 \%$ & $-6.1^{* * *}$ \\
\hline Water & $30.4 \%$ & $10.8 \%$ & $-19.6^{* * *}$ & $55.6 \%$ & $24.0 \%$ & $-31.6^{* * *}$ & $25.6 \%$ & $8.1 \%$ & $-17.5^{* * *}$ \\
\hline Housing & $42.8 \%$ & $22.1 \%$ & $-20.7^{* * *}$ & $90.5 \%$ & $61.5 \%$ & $-29.0 * * *$ & $33.8 \%$ & $14.3 \%$ & $-19.5^{* * *}$ \\
\hline Cooking fuel & $41.6 \%$ & $22.0 \%$ & $-19.5^{* * *}$ & $93.4 \%$ & $60.8 \%$ & $-32.7^{* * *}$ & $31.7 \%$ & $14.3 \%$ & $-17.3^{* * *}$ \\
\hline Assets & $20.8 \%$ & $9.7 \%$ & $-11.0 * * *$ & $60.7 \%$ & $30.6 \%$ & $-30.0 * * *$ & $13.2 \%$ & $5.6 \%$ & $-7.6^{* * *}$ \\
\hline Attendance & $43.5 \%$ & $1.6 \%$ & $-41.9 * * *$ & $79.6 \%$ & $1.0 \%$ & $-78.6^{* * *}$ & $36.7 \%$ & $1.8 \%$ & $-34.9 * * *$ \\
\hline Schooling & $34.0 \%$ & $21.7 \%$ & $-12.2^{* * *}$ & $75.0 \%$ & $59.1 \%$ & $-15.9 * * *$ & $26.2 \%$ & $14.3 \%$ & $-11.9^{* * *}$ \\
\hline Nutrition & $30.0 \%$ & $14.7 \%$ & $-15.4^{* * *}$ & $60.4 \%$ & $38.5 \%$ & $-22.0 * * *$ & $24.3 \%$ & $9.9 \%$ & $-0,143^{* * *}$ \\
\hline
\end{tabular}

The difference between 2006 and 2009 appears in the columns labeled "Difference". ${ }^{* * *}$ implies that this difference is statistically-significant at the 1\% level. The indicators are defined in Table A.4.

\subsection{The Causal Impact of the Programs}

The results above showed that all of the three social-protection schemes we consider are associated with significant reductions in multidimensional poverty. However, we cannot yet draw any causal conclusions for two reasons. First, we found that poverty fell over time irrespective of program participation. Second, the selection of those who participated in the programs was not random. The fundamental challenge with causal inference is that we do not observe what would have happened to the treated had the treatment not occurred, which is a major hurdle in much of the work to date. We here propose to overcome this challenge via a unique longitudinal dataset that enables us to employ robust estimation techniques in a quasi-experimental setting. 
We evaluate program impact by estimating difference-in-differences (DID) models using matching methods to construct a credible control group. The DID estimator will yield the average change in the outcome in the treatment group minus the average change in the same outcome in a control group.

\subsubsection{Identifying the impact of PSNP and Juntos}

To estimate the program effects of PSNP in Ethiopia and Juntos in Peru taking into account non-random program assignment, we use variations of the following regression model:

$$
Y_{i t}=\beta_{0}+\beta_{1} \text { Prog }_{i}+\beta_{2} \text { Post }_{t}+\beta_{3} \text { Prog }_{i} \cdot \text { Post }_{t}+\beta_{4} \boldsymbol{X}_{i t}+\beta_{5} \boldsymbol{Z}_{t}+\lambda_{t}+\varepsilon_{i t}
$$

where $Y_{i t}$ is the outcome variable for household $i$ in year $t$ and $\operatorname{Prog}_{i}$ an indicator of the household's program participation. Post $t_{t}$ is a dummy variable for the post-program periods, $\boldsymbol{X}_{i t}$ a set of time-varying household characteristics, $Z_{t}$ a set of time-varying community characteristics, $\lambda_{t}$ are the year fixed effects and $\varepsilon_{i t}$ the error term. $\beta_{3}$ is our coefficient of interest, which measures the effect of program participation on the outcome variable $Y$. We cluster standard errors at the community level.

In order to separately estimate the short-, medium- and longer-run effects of the programs, we expand equation 1 as follows:

$$
\begin{aligned}
& Y_{i t}=\beta_{0}+\beta_{1} \text { Round }_{t}+\beta_{2} \text { Round }_{t}+\beta_{3} \text { Round }_{t}+\beta_{4} \operatorname{Prog}_{i}+ \\
& \qquad \beta_{5} \operatorname{Prog}_{i} \cdot \text { Round }_{t}+\beta_{6} \operatorname{Prog}_{i} \cdot \text { Round }_{t}+\beta_{7} \operatorname{Prog}_{i} \cdot \operatorname{Round}_{t}+ \\
& \beta_{8} \boldsymbol{X}_{i t}+\beta_{9} \boldsymbol{Z}_{t}+\varepsilon_{i t}
\end{aligned}
$$

where Round $k=3,4,5$ represent the post-program survey waves (see Section 3 for the data description).

To see how social-protection program participation affects well-being, we appeal to a number of different strategies to address identification. One common issue in all the programs we evaluate is selection bias. One key assumption of the DID estimation strategy is that, at baseline, the treatment and comparison groups are as comparable as possible. In other words, the mean change in outcomes for both groups would have been the same in the absence of the program. Unless treatment is randomly assigned, the comparison of the outcomes of participants and non-participants will yield biased estimates.

We check the plausibility of this assumption by assessing whether the pre-treatment trends were the same between the treatment and control groups. If selection is based on observable characteristics, then we can circumvent selection bias by matching on observables. We thus use propensity-score matching methods to construct a comparison group of households with a similar probability of being treated based on observable characteristics. This controls for confounding by matching observations on the basis of their predicted treatment probability using the set of observable characteristics (assumed not to be affected by the treatment). 
In the PSNP case, treatment is largely based on asset and income variables that are observable both to policy makers and the analyst. According to the PSNP implementation manual and previous work (Berhane et al., 2014; Hoddinott et al., 2012; Andersson et al., 2011; Sharp et al., 2006), the variables used for selection are the status of assets, income from non-agricultural activities and alternative employment, and support from relatives or community. We use the following sets of covariates to match the households defined as participants to non-participants: pre-program household demographic characteristics (age and gender of head, and household size), ownership of land and livestock, experiences of shocks (drought, illness, theft) and household location (urban, rural).

Similarly, in Juntos, we identify controls based on propensity score matching techniques. Following Andersen et al. (2015), exposure to the Juntos program was predicted via a probit model based on Wave-one characteristics, including household wealth, number of household members, rural or urban location, number of household members aged six or under (and the number aged 6-14), the first language being indigenous, mother's characteristics, and interaction and polynomial terms.

\subsubsection{Identifying the impact of NREGA}

For NREGA, we can exploit the staggered roll-out of the social-protection programs across districts to causally identify its impact on a set of well-being indicators. This plausibly-exogenous variation over time and space in implementation allows us to estimate the intent-to-treat effects of the program. We estimate the following DID equation:

$$
Y_{i j t}=\beta_{0}+\beta_{1} \text { Prog }_{i j}+\beta_{2} \text { Post }_{t}+\beta_{3} \text { Prog }_{i j} \cdot \text { Post }_{t}+\beta_{4} \boldsymbol{X}_{i j t}+\gamma_{j}+\lambda_{t}+\varepsilon_{i j t}
$$

where $j$ represents district and $\gamma_{j}$ are district fixed effects.

As the surveys that we use also ask household members directly whether they participate in NREGA, we could estimate average treatment effects. However, this may introduce endogeniety, as households that take up NREGA may at the same time make other decisions that could result in reduced poverty. For the sake of comparison, we also employ a similar strategy to that in the first two programs and construct a comparison group of households using propensity-score matching. The results from these latter two methods appear in the Appendix (Tables A.13 and A.14), and are qualitatively similar to our main results.

\subsubsection{Time trends}

Our identification relies on the assumption that, in the absence of the programs, households that participated in the program and those that did not would have exhibited similar time patterns in our outcome variables. Although there is no statistical test for this assumption, visual inspection often reveals that this assumption seems to hold in the pre-treatment period. We have two rounds of pre-intervention data (the 2002 and 2006 
waves) with which to test the parallel-trend assumption.

Figure 1 presents the trends in the incidence and intensity of poverty for program participants and non-participants. As we noted in Section 3, participant households are relatively poorer than non-participants: this can be seen in the gap between the two time series. However, reassuringly, the pre-program trend for participants and non-participants is similar, as required by our identification strategy. We show additional plots in Appendix $B$ that depict parallel trends using different multidimensional-poverty cutoffs, and other well-being indicators such as asset ownership and the wealth index.

Figure 1: Trends in the Incidence and Intensity of Multidimensional Poverty, by Participation Status
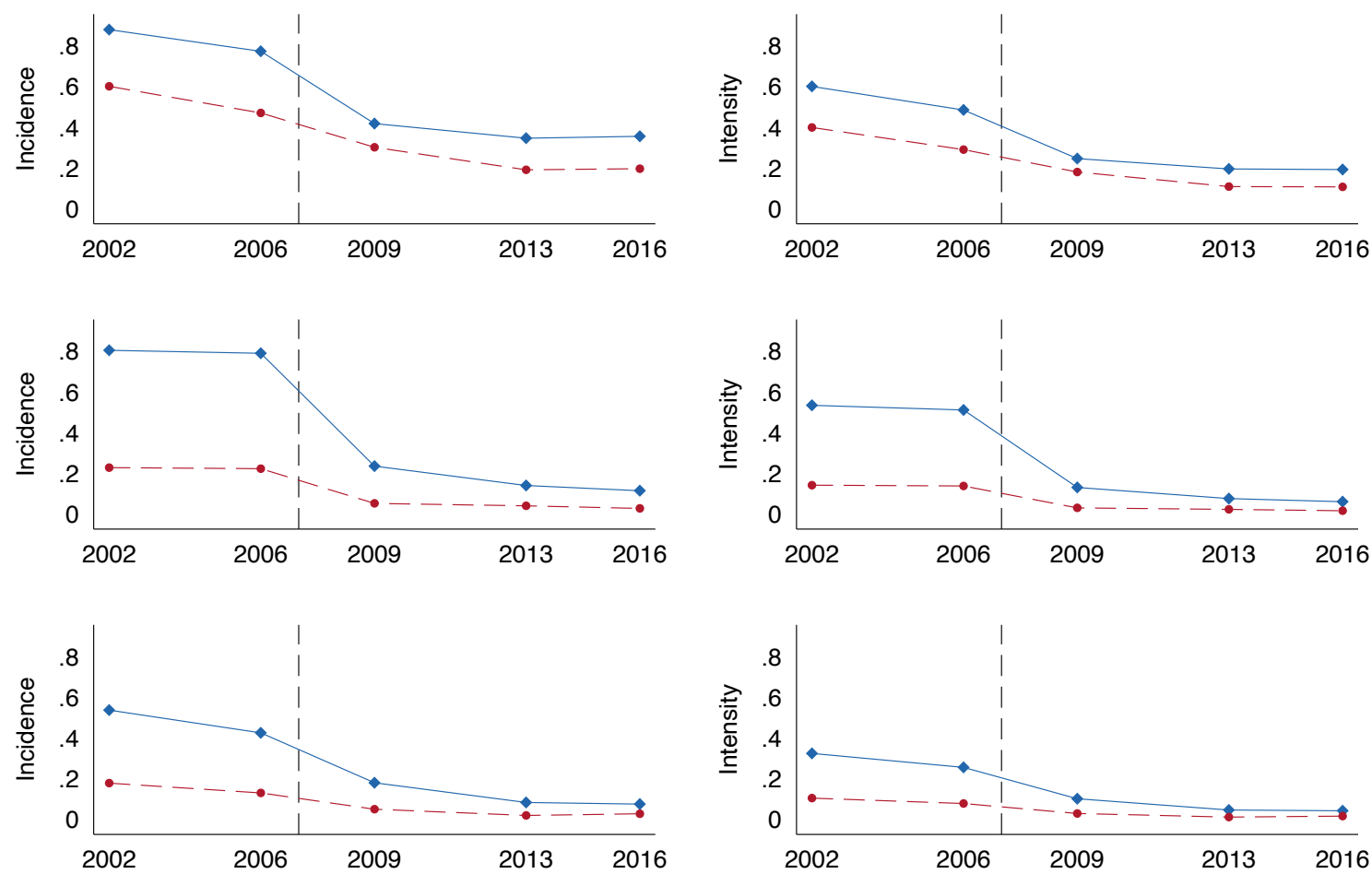

- Participants

- Non-participants

Note: The incidence and intensity of the MPI are calculated based on the deprivation cutoff of $50 \%$ of the weighted indicators.

\subsubsection{Results}

The estimation results from DID estimates of the short-run (2009) and medium- and longerrun (2013 and 2016) impacts of all the three programs appear in Table 4. All of the estimations control for variables that might be affected by the programs and might influence household well-being. These variables include household head's age, education and gender, household 
size, and place of residence (urban/rural). ${ }^{7}$ As the deprivation-score effects on the poor may differ across poverty cutoffs (for example $k=33 \%$ and a higher poverty cutoff, such as $k=$ $50 \%$ ), we also focus on the subset of the poor who experience intense poverty (using $k=50 \%$ ). This approach allows us to establish the distributional impact of the programs on multiple deprivations.

For each country, the first rows labeled Program $\times$ Post shows the average effect of the programs over the three post-implementation survey waves. The subsequent rows list the separate estimated program effects in the short-, medium- and longer-run using data from the third (Program $\times 2009)$, fourth $($ Program $\times 2013)$ and fifth $($ Program $\times 2016)$ survey waves. We show the program effects on both the incidence $(H)$ and intensity $(A)$ of multidimensional poverty. A fall in either $H$ or $A$ reflects a positive program impact.

There are three broad findings in Table 4 in all three countries: the programs significantly reduced the incidence and intensity of poverty for severely-poor households ( $k=50 \%$ ); the average intensity of poverty in all multiply-deprived households fell significantly; and the program effects were largely sustained in the medium- and longer-run.

In Ethiopia and Peru, considering households with three or more deprivations ( $k=33 \%$ ), PSNP and Juntos did not have a statistically-significant impact on the incidence of poverty. However, the corresponding intensities do exhibit a significant fall. NREGA, on the other hand, resulted in a reduction in the incidence of multidimensional poverty by 7.5 percentage points in India (from the $51 \%$ baseline figure). At the same time, the intensity of poverty of those experiencing three or more deprivations fell by 6 percentage-points on average.

Looking at the $k=50 \%$ cutoff level, we find that all three programs significantly reduced the incidence and intensity of poverty. PSNP, NREGA and Juntos produced 11 (from 60\%), 9 (from $25 \%$ ), and 24 (from 48\%) percentage-point declines in the incidence of multidimensional poverty respectively. The corresponding intensities of poverty also significantly fell for all three programs, with figures ranging from $6-18 \%$. These findings suggest that the reductions in multidimensional-poverty incidence are concentrated amongst those with five or more deprivations, and also improving the poverty profiles of those with a larger number of deprivations.

We next ask which deprivations fell the most. We estimate the program impact on all 10 censored deprivation indicators. Table 5 presents the dimensional decomposition and the contribution of the indicators to overall poverty. The reductions in deprivation are not uniform across indicators. In all the three programs, the reduction in multidimensional poverty has been accomplished by large falls in deprivation in "asset ownership" and "school attendance". There were statistically-significant reductions in "sanitation" in both Peru and Ethiopia, "schooling" and "electricity" in Peru, and "housing" and "nutrition" in India. We find no significant reductions in the "cooking fuel" and "clean water" indicators in any country.

The short- and longer-run effects of the three programs on the censored indicators appear in Tables A.9 - A.11 in Appendix A. The probability of not owning two or more durable assets

\footnotetext{
${ }^{7}$ We also run the estimations without these control variables and find very similar results. Table A.16 in Appendix A reports these results.
} 
Table 4: DID Estimations: Short- and Longer-run effects

\begin{tabular}{|c|c|c|c|c|}
\hline & \multicolumn{2}{|c|}{ Incidence of Poverty } & \multicolumn{2}{|c|}{ Intensity of Poverty } \\
\hline & $k=33 \%$ & $k=50 \%$ & $k=33 \%$ & $k=50 \%$ \\
\hline \multicolumn{5}{|l|}{ Ethiopia } \\
\hline Program $\times$ Post & $\begin{array}{c}0.055 \\
(0.033)\end{array}$ & $\begin{array}{l}-0.1111^{* *} \\
(0.039)\end{array}$ & $\begin{array}{c}-0.034^{* *} \\
(0.012)\end{array}$ & $\begin{array}{c}-0.089 * * * \\
(0.019)\end{array}$ \\
\hline Program × 2009 & $\begin{array}{c}0.018 \\
(0.035)\end{array}$ & $\begin{array}{c}-0.192^{* * *} \\
(0.042)\end{array}$ & $\begin{array}{c}-0.063^{* * *} \\
(0.021)\end{array}$ & $\begin{array}{c}-0.143^{* * *} \\
(0.022)\end{array}$ \\
\hline Program $\times 2013$ & $\begin{array}{l}0.098^{*} \\
(0.051)\end{array}$ & $\begin{array}{c}-0.086^{* *} \\
(0.035)\end{array}$ & $\begin{array}{r}-0.009 \\
(0.015)\end{array}$ & $\begin{array}{c}-0.080^{* * *} \\
(0.020)\end{array}$ \\
\hline Program $\times 2016$ & $\begin{array}{c}0.060 \\
(0.039)\end{array}$ & $\begin{array}{l}-0.092^{*} \\
(0.045)\end{array}$ & $\begin{array}{l}-0.023 \\
(0.024)\end{array}$ & $\begin{array}{c}-0.078^{* * *} \\
(0.025)\end{array}$ \\
\hline $\begin{array}{l}\text { Observations } \\
\text { Control mean }\end{array}$ & $\begin{array}{l}7142 \\
0.86\end{array}$ & $\begin{array}{c}7033 \\
0.60\end{array}$ & $\begin{array}{l}7198 \\
0.48\end{array}$ & $\begin{array}{l}7125 \\
0.38\end{array}$ \\
\hline \multicolumn{5}{|l|}{ India } \\
\hline Program $\times$ Post & $\begin{array}{c}-0.075^{* *} \\
(0.028)\end{array}$ & $\begin{array}{c}-0.093^{*} \\
(0.047)\end{array}$ & $\begin{array}{c}-0.059^{* *} \\
(0.021)\end{array}$ & $\begin{array}{c}-0.056 * \\
(0.032)\end{array}$ \\
\hline Program × 2009 & $\begin{array}{c}-0.078^{* * *} \\
(0.026)\end{array}$ & $\begin{array}{l}-0.064 \\
(0.041)\end{array}$ & $\begin{array}{c}-0.041^{* *} \\
(0.017)\end{array}$ & $\begin{array}{l}-0.045 \\
(0.026)\end{array}$ \\
\hline Program $\times 2013$ & $\begin{array}{l}-0.112^{* *} \\
(0.047)\end{array}$ & $\begin{array}{c}-0.123^{* *} \\
(0.055)\end{array}$ & $\begin{array}{c}-0.065^{* *} \\
(0.027)\end{array}$ & $\begin{array}{l}-0.055 \\
(0.035)\end{array}$ \\
\hline Program × 2016 & $\begin{array}{c}-0.102^{* *} \\
(0.038)\end{array}$ & $\begin{array}{l}-0.094 \\
(0.057)\end{array}$ & $\begin{array}{l}-0.037 \\
(0.029)\end{array}$ & $\begin{array}{l}-0.047 \\
(0.037)\end{array}$ \\
\hline $\begin{array}{l}\text { Observations } \\
\text { Control mean }\end{array}$ & $\begin{array}{c}9082 \\
0.51\end{array}$ & $\begin{array}{l}9879 \\
0.25\end{array}$ & $\begin{array}{l}9886 \\
0.26\end{array}$ & $\begin{array}{c}9880 \\
0.16\end{array}$ \\
\hline \multicolumn{5}{|l|}{ Peru } \\
\hline Program $\times$ Post & $\begin{array}{l}-0.019 \\
(0.040)\end{array}$ & $\begin{array}{c}-0.237^{* * *} \\
(0.054)\end{array}$ & $\begin{array}{c}-0.097^{* * *} \\
(0.024)\end{array}$ & $\begin{array}{c}-0.182^{* * *} \\
(0.042)\end{array}$ \\
\hline Program × 2009 & $\begin{array}{c}0.067 \\
(0.048)\end{array}$ & $\begin{array}{c}-0.196 * * * \\
(0.057)\end{array}$ & $\begin{array}{c}-0.080 * * * \\
(0.023)\end{array}$ & $\begin{array}{c}-0.164^{* * *} \\
(0.044)\end{array}$ \\
\hline Program $\times 2013$ & $\begin{array}{l}-0.038 \\
(0.043)\end{array}$ & $\begin{array}{c}-0.253^{* * *} \\
(0.067)\end{array}$ & $\begin{array}{c}-0.075^{* *} \\
(0.029)\end{array}$ & $\begin{array}{c}-0.191^{* * *} \\
(0.043)\end{array}$ \\
\hline Program $\times 2016$ & $\begin{array}{l}-0.023 \\
(0.062)\end{array}$ & $\begin{array}{c}-0.247^{* * *} \\
(0.059)\end{array}$ & $\begin{array}{c}-0.112 * * * \\
(0.034)\end{array}$ & $\begin{array}{c}-0.169 * * * \\
(0.043)\end{array}$ \\
\hline $\begin{array}{l}\text { Observations } \\
\text { Control mean }\end{array}$ & $\begin{array}{c}6563 \\
0.72\end{array}$ & $\begin{array}{l}6698 \\
0.48\end{array}$ & $\begin{array}{l}6752 \\
0.40\end{array}$ & $\begin{array}{l}6757 \\
0.30\end{array}$ \\
\hline
\end{tabular}

Each cell is from a separate DID estimation of the outcome variable indicated in the column headings. Standard errors clustered at the community level in parentheses. ${ }^{*} p<0.01$, ${ }^{* *}$ $p<0.05$, *** $p<0.001$ 
was 30 percentage points lower for PSNP program participants in Ethiopia almost 10 years after the introduction of the program. Similarly, deprivation in asset holdings fell by 10 and 31 percentage points respectively for NREGA and Juntos participants in India and Peru.

It seems that the positive effect of the two public-works programs mainly captures the direct income effect of the benefits (wages and in-kind transfers) received. These results are consistent with most findings in the related literature. Similar to our NREGA and PSNP findings, a systematic review of 28 evaluations of public-works programs in Africa and the Middle East in Beierl and Grimm (2018) finds that public-works programs bring about a moderate increase in asset accumulation and have some success in consumption smoothing. They find little evidence of any program impact on child nutrition.

With regard to Juntos, the two key characteristics of a CCT program are that they simultaneously act upon the short- and long-run dimensions of poverty. Our results highlight the impacts of a cash transfer on both current poverty and the conditioning of the transfer on school attendance: Juntos reduced the incidence and intensity of multidimensional poverty particularly through greater asset ownership and the school attendance of children.

\subsection{Robustness Checks}

We carry out a number of robustness checks of our main analyses. We first expand the main analysis of the multidimensional-poverty effects to other indicators of wellbeing, such as the household wealth index, livestock holdings, and susceptibility to natural and economic shocks. Table A.12 in Appendix A presents these results. We find that all three programs have a positive sustained impact on livestock holdings in Ethiopia and Peru. In addition, in India, susceptibility to drought-induced shocks fell significantly for program participants over the 10 years considered.

As a robustness test of the parallel-trend assumption, we consider a placebo program implementation three years earlier than the actual implementation date. We use data from the 2002 and 2006 waves of the survey for this exercise. We maintain the original assignment of districts to program in India and participant households in Ethiopia and Peru. We then re-estimate our model on this sample. Table A.15 in Appendix A reports the results. The estimated placebo effects are statistically insignificant across the three programs, lending support to our claim that there were no confounding differential trends in the pre-program period.

We last checked the robustness of our results to different deprivation and poverty cutoffs. We calculate the MPI for the three countries using slightly different deprivation and poverty cutoffs, as well as weights attached to the indicators. The results are largely consistent with our main findings and are available from the authors upon request. 


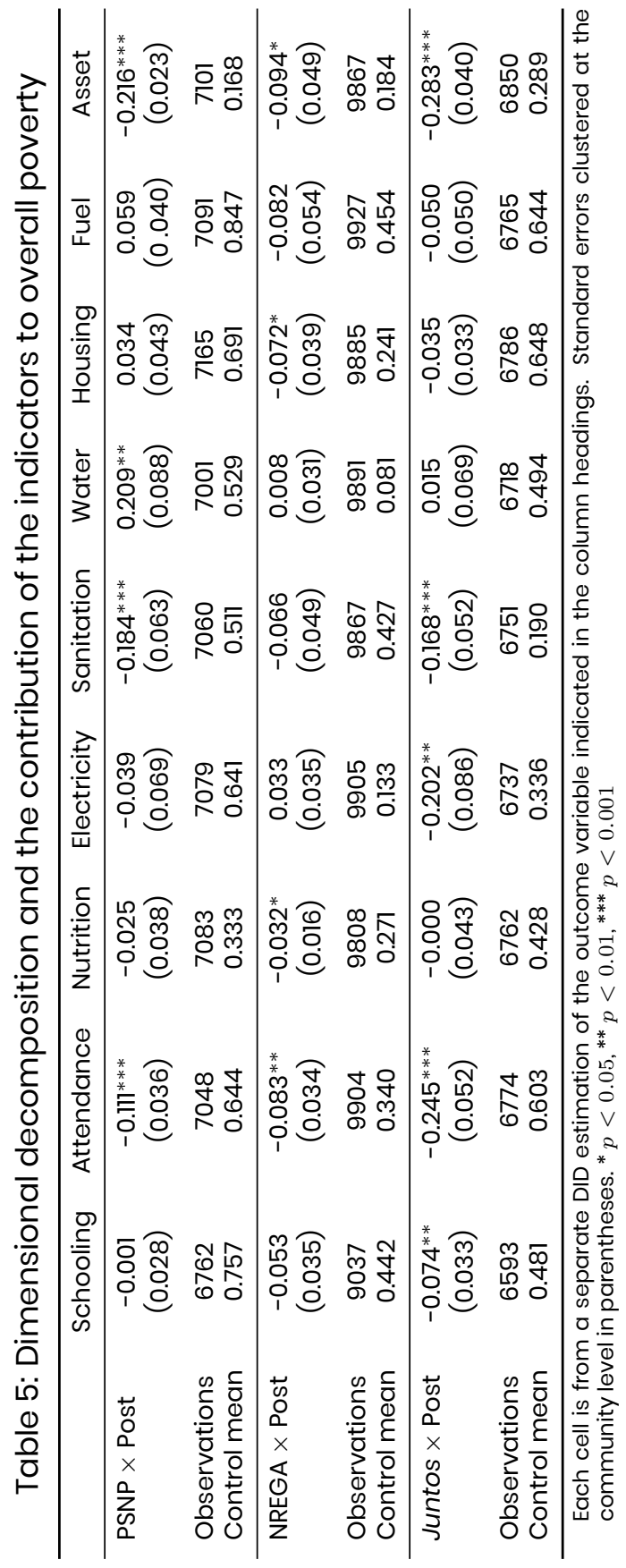




\section{Conclusions}

Social-protection schemes have become a popular form of government intervention in developing countries. There is also a renewed emphasis on these programs within the international development community, as they are seen as a tool to combat the adverse impacts of natural and economic crises. However, the empirical evidence on their effectiveness remains mixed.

In this paper we go beyond the analysis of average outcomes and investigate the impact on multidimensional poverty of three large-scale social-protection schemes - the Productive Safety Net Program (PSNP) in Ethiopia, the Mahatma Gandhi National Rural Employment Guarantee Act (NREGA) in India, and the Juntos conditional cash-transfer program in Peru. We use five waves of panel data collected simultaneously from 2002 to 2016 in all three of these countries.

The novelty of our study is the evaluation of the social-protection schemes using multidimensional poverty measures. Following the Alkire-Foster method of measuring multidimensional poverty, we consider 10 poverty indicators grouped into three dimensions: Education, Health, and Standard of Living. We consider different poverty cutoffs to clearly indicate the distributional impact of the programs on both the incidence and intensity of multidimensional poverty.

We find descriptive evidence that, on average, poorer households are successfully targeted by the programs. We show that multidimensional poverty (both incidence and intensity) declined in all three countries over the 2006 - 2016 period. The size of this fall varies across countries and by social-protection program participation. Overall, participation in social safety-nets is associated with a larger drop in all of the multidimensional poverty indicators. We also calculated the contribution of each dimension to multidimensional poverty. The decomposition of multidimensional poverty into the three dimensions reveals that deprivation in the education dimension accounts for over half of multidimensional poverty in Ethiopia and Peru, and two thirds in India. Deprivation in living conditions is the second dimension that contributes the most to overall poverty.

We then evaluate the effect of these programs on multidimensional well-being in a difference-in-difference framework over both the shorter and longer-run. Social protection programs significantly reduced the incidence and intensity of poverty for severely-poor households in all the three countries. The intensity of poverty of households experiencing multiple deprivations is significantly reduced in all of the samples we analyze. These program effects were sustained in the medium- and longer-run in all three countries. In contexts where chronic poverty and underemployment are widespread and persistent throughout the year, public-work programs that pay adequate wages over an extended period may enable beneficiaries to accumulate assets and make productive investments. The estimation results further indicate a positive short-run impact on asset formation, livestock holding, and some living-standard indicators.

These results show that the use of multidimensional poverty indicators, in addition to monetary measures, may help in monitoring the trends and understanding the dynamics 
of poverty, and in evaluating the efficacy of policy measures such as the social-protection schemes considered here. In addition, these findings provide information that can revealing a country's deprivation structure and help with policy targeting. 


\section{References}

Afridi, F., Mukhopadhyay, A., and Sahoo, S. (2016). Female labor force participation and child education in India: Evidence from the National Rural Employment Guarantee Scheme. IZA Journal of Labor \& Development, 5:7.

Alderman, $H$. and Yemtsov, R. (2014). How Can Safety Nets Contribute to Economic Growth? World Bank Economic Review, 28:1-20.

Alkire, S., Chatterjee, M., Conconi, A., Seth, S., and Vaz, A. (2014). Global multidimensional poverty index 2014. Technical report, OPHI Working Paper 121, University of Oxford.

Alkire, S. and Foster, J. (2011). Counting and multidimensional poverty measurement. Journal of Public Economics, 95:476487.

Alkire, S. and Jahan, S. (2018). The New Global MPI 2018: Aligning with the Sustainable Development Goals. Technical report, OPHI Working Paper 121, University of Oxford.

Alkire, S. and Seth, S. (2015). Multidimensional poverty reduction in India between 1999 and 2006:
Where and how? World Development, 72:93-108.

Andersen, C. T., Reynolds, S. A., Behrman, J. R., Crookston, B. T., Dearden, K. A., Escobal, J., Mani, S., Sánchez, A., Stein, A. D., and Fernald, L. C. (2015). Participation in the Juntos Conditional Cash Transfer Program in Peru is associated with changes in child anthropometric status but not language development or school achievement. Journal of Nutrition, 145:2396-2405.

Andersson, C., Mekonnen, A., and Stage, J. (2011) Impacts of the Productive Safety Net Program in Ethiopia on livestock and tree holdings of rural households. Journal of Development Economics, 94:119-126.

Angelucci, $M$. and De Giorgi, G. (2009). Indirect effects of an aid program: How do cash transfers affect ineligibles consumption? American Economic Review, 99:486508.

Atkinson, A. B. (2003) Multidimensional

deprivation: Contrasting social welfare and counting approaches. Journal of Economic Inequality, 1:51-65.

Beierl, S. and Grimm, M. (2018). Do public works programs work? A systematic review of the evidence from programmes in low and lower-middle income countries in Africa and the MENA region. Technical report, Deutsche Gesellschaft fur Internationale Zusammenarbeit (GIZ).

Berg, E., Bhattacharyya, S., Rajasekhar, D., and Manjula, R. (2018). Can public works increase equilibrium wages? Evidence from India's National Rural Employment Guarantee. World Development, 103:239-254.

Berhane, G., Gilligan, D. O., Hoddinott, J., Kumar, N., and Taffesse, A. S. (2014). Can social protection work in Africa? The impact of Ethiopia's productive safety net programme. Economic Development and Cultural Change, 63:1-26.

Bertrand, M., Crépon, B., Marguerie, A., and Premand, P. (2017). Contemporaneous and post-program impacts of a public works program: Evidence from Côte d'Ivoire. Mimeo.

Bose, N. (2017). Raising consumption through India's National Rural Employment Guarantee 
Scheme.

World

Development, 96:245-

263.

Cookson, T. P. (2015). Rural women and the uneven process of inclusion: An institutional ethnography of Peru's conditional cash transfer programme. PhD thesis, University of Cambridge.

Cunha, J. M., De Giorgi, G., and Jayachandran, $S$. (2019). The price effects of cash versus in-kind transfers. Review of Economics and Statistics, 86:240-281.

Dasgupta, A. (2017). Can the major public works policy buffer negative shocks in early childhood? Evidence from Andhra Pradesh, India. Economic Development and Cultural Change, 65:767-804.

Escobal, J. and Flores, E. (2008). An assessment of the Young Lives sampling approach in Peru. Technical report, Young Lives.

Fiszbein, A. and Schady, N. R. (2009). Conditional cash transfers: reducing present and future poverty. The World Bank.

Galasso, E. and Ravallion, M. (2004). Social protection in a crisis: Argentina's Plan Jefes y Jefas. World Bank
Economic Review, 18:367399.

Gehrke, E. (2017). An employment guarantee as risk Insurance? Assessing the effects of the NREGS on agricultural production decisions. World Bank Economic Review, 1:23.

Gehrke, E. and Hartwig, $R$. (2018). Productive effects of public works programs: What do we know? What should we know? World Development, 107:111-124.

Gilligan, D. O., Hoddinott, J., and Taffesse, A. S. (2009). The impact of Ethiopia's Productive Safety Net Programme and its linkages. Journal of Development Studies, 45:1684-1706.

Grosh, M. E. and Baker, J. L. (1995). Proxy means tests for targeting social programs: Simulations and speculation. The World Bank.

Hanna, R. and Karlan, D. (2017). Designing social Protection Programs: Using Theory and Experimentation to Understand How to Help Combat Poverty. In Banerjee, A. V. and Duflo, E., editors, Handbook of Economic Field Experiments, volume 2 of Handbook of Economic
Field Experiments, pages 515 - 553. North-Holland.

Hanna, R. and Olken, B. A. (2018). Universal basic incomes versus targeted transfers: Anti-poverty programs in developing countries. Journal of Economic Perspectives, 32:201-26.

Hoddinott, J., Berhane, G., Gilligan, D. O., Kumar, N., and Seyoum Taffesse, A. (2012). The impact of Ethiopia's Productive Safety Net Programme and related transfers on agricultural productivity. Journal of African Economies, 21:761-786.

Imbert, C. and Papp, J. (2015). Labor market effects of social programs: Evidence from India's employment guarantee. American Economic Journal: Applied Economics, 7:233-263.

Jalan, J. and Ravallion, M. (2003). Estimating the benefit incidence of an antipoverty program by propensity-score matching. Journal of Business \& Economic Statistics, 21:19-30.

Kabeer, N. and Waddington, H. (2015). Economic impacts of conditional cash transfer programmes: a systematic review and meta-analysis. 
Journal of Development Effectiveness, 7:290-303.

Kumra, N. (2008). An assessment of the Young Lives sampling approach in Andhra Pradesh, India. Technical report, Young Lives Technical Note 2. Oxford: Young Lives.

Li, T. and Sekhri, S. (2013). The unintended consequences of employment based safety net. Mimeo.

Molina Millan, T., Barham, T. C. J., Macours, K., Maluccio, J. A., and Stampini, M. (2016). Long-term impacts of conditional cash transfers in Latin America: Review of the evidence. Technical report, IDB Working Paper Series.

Murgai, R., Ravallion, M., and van de Walle, D. (2016). Is workfare cost-effective against poverty in a poor labor-surplus economy? World Bank Economic Review, 30:413-445.

Olivier de Sardan, J.P. and Piccoli, E. (2017). Cash transfers: the revenge of contexts, an anthropological approach. In Olivier de Sardan, J.-P. and Piccoli, E., editors, Cash transfers in context: An anthropological perspective, pages 1 27.
Outes-Leon, I. and Dercon, S. (2008). Survey attrition and attrition bias in Young Lives. Technical report, Young Lives Technical Note 5, Oxford: Young Lives.

Outes-Leon, I. and Sanchez, A. (2008). An assesment of the Young Lives sampling approach in Ethiopia. Technical report, Young Lives Technical Notes 1. Oxford: Young Lives.

Page, L. and Pande, $\mathbf{R}$. (2018). Ending global poverty: Why money isn't enough. Journal of Economic Perspectives, 32:173-200.

Perova, E. and Vakis, $R$. (2012). 5 years in Juntos: New evidence on the program's short and longterm impacts. Revista Economía, 35:53-82.

Porter, C. and Goyal, R. (2016). Social protection for all ages? Impacts of Ethiopia's Productive Safety Net Program on child nutrition. Social Science \& Medicine, 159:92-99.

Saavedra, J. E., García, S., et al. (2012). Impacts of conditional cash transfer programs on educational outcomes in developing countries: A meta-analysis. RAND Labor and Population
Working Paper Series, WR-921-1.

Sánchez, A., Meléndez, G., and Behrman, J. r. (2020). Impact of the Juntos Conditional Cash Transfer program on nutritional and cognitive outcomes in Peru: Comparison between younger and older initial exposure. Economic Development and Cultural Change, 68:865-897.

Seth, S. and Tutor, M. V. (2019). Evaluation of antipoverty programs' impact on joint disadvantages: Insights from the philippine experience. Technical report, Queen Elizabeth House, University of Oxford.

Shah, M. and Steinberg, B. M. (2019). Workfare and human capital investment: Evidence from India. Journal of Human Resources, 56:11179201R2.

Sharp, K., Brown, T., and Teshome, A. (2006). Targeting Ethiopia's Productive Safety Net Programme (PSNP). Overseas Development Institute and the IDL Group: London and Bristol, UK.

Sulaiman, M. (2016). Making sustainable reduction in extreme poverty: A comparative meta-analysis of 
livelihood, cash transfer and graduation approaches. Technical report, Washington, DC: CGAP.

UNDP (2010). The real wealth of nations:
Pathways to human development. Technical report, United Nations Development Program.

World Bank (2018). The state of social safety nets 2018. World Bank,
Washington, DC.

Zimmermann, L. (2014). Public works programs in developing countries have the potential to reduce poverty. IZA World of Labor. 


\section{A. Additional Tables}

Table A.l: Summary Statistics (by Treatment Status): Ethiopia

\begin{tabular}{|c|c|c|c|c|c|c|}
\hline & \multicolumn{3}{|c|}{$\begin{array}{l}\text { Pre-program } \\
\quad(2006)\end{array}$} & \multicolumn{3}{|c|}{$\begin{array}{l}\text { Post-program } \\
(2009-2016)\end{array}$} \\
\hline & All & $P$ & NP & All & $P$ & NP \\
\hline \multicolumn{7}{|c|}{ Household head: } \\
\hline Education & $\begin{array}{c}3.57 \\
(3.78)\end{array}$ & $\begin{array}{c}1.70 \\
(2.23)\end{array}$ & $\begin{array}{c}4.29 \\
(4.01)\end{array}$ & $\begin{array}{c}4.73 \\
(3.92)\end{array}$ & $\begin{array}{c}2.56 \\
(2.44)\end{array}$ & $\begin{array}{c}5.29 \\
(4.03)\end{array}$ \\
\hline Age & $\begin{array}{l}42.91 \\
(11.45)\end{array}$ & $\begin{array}{l}43.16 \\
(11.84)\end{array}$ & $\begin{array}{l}42.82 \\
(11.30)\end{array}$ & $\begin{array}{c}47.11 \\
(12.07)\end{array}$ & $\begin{array}{l}47.36 \\
(11.62)\end{array}$ & $\begin{array}{l}47.05 \\
(12.19)\end{array}$ \\
\hline Male & $\begin{array}{c}0.79 \\
(0.41)\end{array}$ & $\begin{array}{c}0.73 \\
(0.44)\end{array}$ & $\begin{array}{c}0.81 \\
(0.39)\end{array}$ & $\begin{array}{c}0.75 \\
(0.44)\end{array}$ & $\begin{array}{c}0.68 \\
(0.47)\end{array}$ & $\begin{array}{c}0.76 \\
(0.42)\end{array}$ \\
\hline Household size & $\begin{array}{c}6.20 \\
(2.08)\end{array}$ & $\begin{array}{l}6.23 \\
(1.95)\end{array}$ & $\begin{array}{c}6.19 \\
(2.13)\end{array}$ & $\begin{array}{l}5.80 \\
(2.10)\end{array}$ & $\begin{array}{l}5.87 \\
(1.99)\end{array}$ & $\begin{array}{l}5.78 \\
(2.12)\end{array}$ \\
\hline Wealth index & $\begin{array}{c}0.29 \\
(0.18)\end{array}$ & $\begin{array}{c}0.21 \\
(0.12)\end{array}$ & $\begin{array}{c}0.32 \\
(0.18)\end{array}$ & $\begin{array}{c}0.37 \\
(0.17)\end{array}$ & $\begin{array}{c}0.28 \\
(0.13)\end{array}$ & $\begin{array}{c}0.40 \\
(0.18)\end{array}$ \\
\hline \multicolumn{7}{|c|}{ Access to services } \\
\hline Water & $\begin{array}{c}0.50 \\
(0.50)\end{array}$ & $\begin{array}{c}0.50 \\
(0.50)\end{array}$ & $\begin{array}{c}0.51 \\
(0.50)\end{array}$ & $\begin{array}{c}0.55 \\
(0.50)\end{array}$ & $\begin{array}{c}0.37 \\
(0.48)\end{array}$ & $\begin{array}{c}0.60 \\
(0.49)\end{array}$ \\
\hline Sanitation & $\begin{array}{c}0.40 \\
(0.49)\end{array}$ & $\begin{array}{c}0.31 \\
(0.46)\end{array}$ & $\begin{array}{c}0.44 \\
(0.50)\end{array}$ & $\begin{array}{c}0.63 \\
(0.48)\end{array}$ & $\begin{array}{c}0.65 \\
(0.48)\end{array}$ & $\begin{array}{c}0.62 \\
(0.48)\end{array}$ \\
\hline Electricity & $\begin{array}{c}0.44 \\
(0.50)\end{array}$ & $\begin{array}{c}0.20 \\
(0.40)\end{array}$ & $\begin{array}{c}0.53 \\
(0.50)\end{array}$ & $\begin{array}{c}0.60 \\
(0.49)\end{array}$ & $\begin{array}{c}0.41 \\
(0.49)\end{array}$ & $\begin{array}{c}0.65 \\
(0.48)\end{array}$ \\
\hline \multicolumn{7}{|c|}{ Household owns } \\
\hline Livestock & $\begin{array}{c}0.66 \\
(0.47)\end{array}$ & $\begin{array}{c}0.81 \\
(0.39)\end{array}$ & $\begin{array}{c}0.60 \\
(0.49)\end{array}$ & $\begin{array}{c}0.69 \\
(0.46)\end{array}$ & $\begin{array}{c}0.87 \\
(0.34)\end{array}$ & $\begin{array}{c}0.64 \\
(0.48)\end{array}$ \\
\hline Land & $\begin{array}{c}0.77 \\
(0.42)\end{array}$ & $\begin{array}{c}0.86 \\
(0.35)\end{array}$ & $\begin{array}{c}0.73 \\
(0.45)\end{array}$ & $\begin{array}{c}0.81 \\
(0.40)\end{array}$ & $\begin{array}{c}0.88 \\
(0.32)\end{array}$ & $\begin{array}{c}0.78 \\
(0.41)\end{array}$ \\
\hline House & $\begin{array}{c}0.72 \\
(0.45)\end{array}$ & $\begin{array}{c}0.85 \\
(0.35)\end{array}$ & $\begin{array}{c}0.67 \\
(0.47)\end{array}$ & $\begin{array}{c}0.73 \\
(0.44)\end{array}$ & $\begin{array}{c}0.88 \\
(0.33)\end{array}$ & $\begin{array}{c}0.69 \\
(0.46)\end{array}$ \\
\hline Shock-drought & $\begin{array}{l}\text { t } 0.29 \\
(0.45)\end{array}$ & $\begin{array}{c}0.51 \\
(0.50)\end{array}$ & $\begin{array}{c}0.21 \\
(0.41)\end{array}$ & $\begin{array}{c}0.22 \\
(0.42)\end{array}$ & $\begin{array}{c}0.41 \\
(0.49)\end{array}$ & $\begin{array}{c}0.17 \\
(0.38)\end{array}$ \\
\hline Observations & 2892 & 805 & 2087 & 8304 & 1753 & 6551 \\
\hline
\end{tabular}


Table A.2: Summary Statistics (by Treatment Status): India

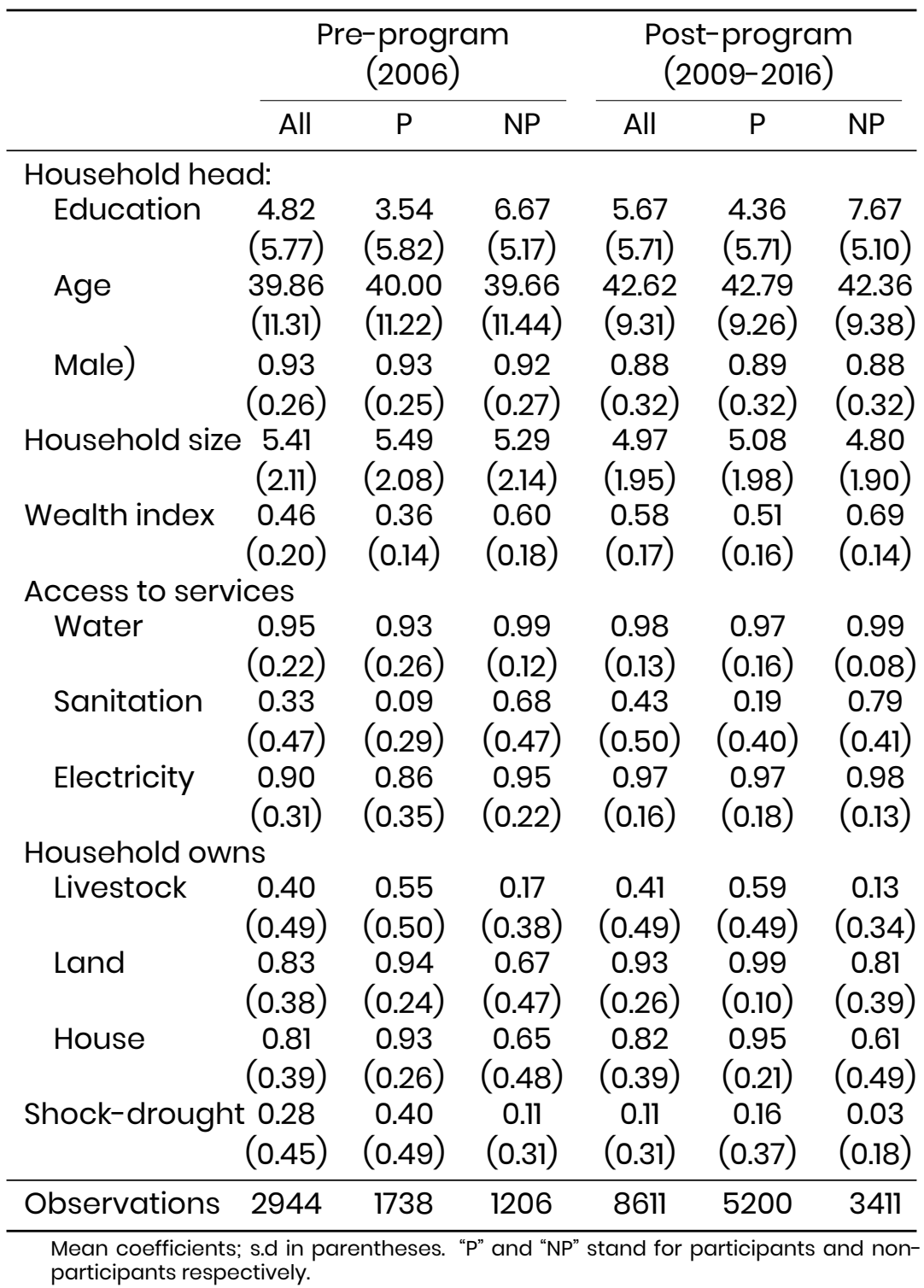


Table A.3: Summary Statistics (by Treatment Status): Peru

\begin{tabular}{|c|c|c|c|c|c|c|}
\hline & \multicolumn{3}{|c|}{$\begin{array}{l}\text { Pre-program } \\
\text { (2006) }\end{array}$} & \multicolumn{3}{|c|}{$\begin{array}{l}\text { Post-program } \\
\text { (2009-2016) }\end{array}$} \\
\hline & All & $P$ & NP & All & $\mathrm{P}$ & NP \\
\hline \multicolumn{7}{|c|}{ Household head: } \\
\hline Education & $\begin{array}{c}7.76 \\
(4.28)\end{array}$ & $\begin{array}{c}4.31 \\
(3.10)\end{array}$ & $\begin{array}{c}8.41 \\
(4.15)\end{array}$ & $\begin{array}{c}8.38 \\
(4.27)\end{array}$ & $\begin{array}{l}5.05 \\
(3.37)\end{array}$ & $\begin{array}{c}9.14 \\
(4.08)\end{array}$ \\
\hline Age & $\begin{array}{l}39.82 \\
(11.27)\end{array}$ & $\begin{array}{l}39.07 \\
(11.03)\end{array}$ & $\begin{array}{l}39.96 \\
(11.31)\end{array}$ & $\begin{array}{l}43.24 \\
(11.32)\end{array}$ & $\begin{array}{l}44.06 \\
(10.39)\end{array}$ & $\begin{array}{l}43.06 \\
(11.50)\end{array}$ \\
\hline Male & $\begin{array}{c}0.87 \\
(0.34)\end{array}$ & $\begin{array}{c}0.90 \\
(0.30)\end{array}$ & $\begin{array}{c}0.86 \\
(0.34)\end{array}$ & $\begin{array}{c}0.82 \\
(0.39)\end{array}$ & $\begin{array}{c}0.86 \\
(0.35)\end{array}$ & $\begin{array}{c}0.81 \\
(0.39)\end{array}$ \\
\hline Household size & $\begin{array}{c}5.52 \\
(2.06)\end{array}$ & $\begin{array}{c}6.20 \\
(1.94)\end{array}$ & $\begin{array}{c}5.40 \\
(2.05)\end{array}$ & $\begin{array}{c}5.18 \\
(1.94)\end{array}$ & $\begin{array}{c}5.75 \\
(1.85)\end{array}$ & $\begin{array}{l}5.05 \\
(1.93)\end{array}$ \\
\hline Wealth index & $\begin{array}{c}0.48 \\
(0.23)\end{array}$ & $\begin{array}{l}0.25 \\
(0.12)\end{array}$ & $\begin{array}{c}0.52 \\
(0.22)\end{array}$ & $\begin{array}{l}0.60 \\
(0.19)\end{array}$ & $\begin{array}{l}0.40 \\
(0.12)\end{array}$ & $\begin{array}{c}0.64 \\
(0.18)\end{array}$ \\
\hline \multicolumn{7}{|c|}{ Access to services } \\
\hline Water & $\begin{array}{c}0.62 \\
(0.48)\end{array}$ & $\begin{array}{c}0.44 \\
(0.50)\end{array}$ & $\begin{array}{c}0.66 \\
(0.47)\end{array}$ & $\begin{array}{c}0.82 \\
(0.39)\end{array}$ & $\begin{array}{c}0.69 \\
(0.46)\end{array}$ & $\begin{array}{c}0.84 \\
(0.36)\end{array}$ \\
\hline Sanitation & $\begin{array}{c}0.85 \\
(0.35)\end{array}$ & $\begin{array}{c}0.68 \\
(0.47)\end{array}$ & $\begin{array}{c}0.89 \\
(0.32)\end{array}$ & $\begin{array}{c}0.94 \\
(0.24)\end{array}$ & $\begin{array}{c}0.91 \\
(0.28)\end{array}$ & $\begin{array}{c}0.95 \\
(0.23)\end{array}$ \\
\hline Electricity & $\begin{array}{c}0.77 \\
(0.42)\end{array}$ & $\begin{array}{c}0.48 \\
(0.50)\end{array}$ & $\begin{array}{c}0.83 \\
(0.38)\end{array}$ & $\begin{array}{c}0.93 \\
(0.26)\end{array}$ & $\begin{array}{c}0.85 \\
(0.36)\end{array}$ & $\begin{array}{c}0.94 \\
(0.23)\end{array}$ \\
\hline \multicolumn{7}{|c|}{ Household owns } \\
\hline Livestock & $\begin{array}{c}0.63 \\
(0.48)\end{array}$ & $\begin{array}{c}0.98 \\
(0.15)\end{array}$ & $\begin{array}{c}0.57 \\
(0.50)\end{array}$ & $\begin{array}{c}0.57 \\
(0.49)\end{array}$ & $\begin{array}{l}0.95 \\
(0.21)\end{array}$ & $\begin{array}{c}0.48 \\
(0.50)\end{array}$ \\
\hline Land & & & & $\begin{array}{c}0.77 \\
(0.42)\end{array}$ & $\begin{array}{c}0.87 \\
(0.33)\end{array}$ & $\begin{array}{c}0.74 \\
(0.44)\end{array}$ \\
\hline House & $\begin{array}{c}0.71 \\
(0.45)\end{array}$ & $\begin{array}{c}0.86 \\
(0.35)\end{array}$ & $\begin{array}{c}0.68 \\
(0.47)\end{array}$ & $\begin{array}{c}0.78 \\
(0.42)\end{array}$ & $\begin{array}{c}0.90 \\
(0.30)\end{array}$ & $\begin{array}{c}0.75 \\
(0.43)\end{array}$ \\
\hline Shock-drought & $\begin{array}{l}\text { t } 0.07 \\
(0.25)\end{array}$ & $\begin{array}{c}0.22 \\
(0.41) \\
\end{array}$ & $\begin{array}{c}0.04 \\
(0.19) \\
\end{array}$ & $\begin{array}{c}0.05 \\
(0.22) \\
\end{array}$ & $\begin{array}{c}0.18 \\
(0.38) \\
\end{array}$ & $\begin{array}{c}0.02 \\
(0.15) \\
\end{array}$ \\
\hline Observations & 2766 & 427 & 2339 & 7771 & 1378 & 6393 \\
\hline
\end{tabular}


Table A.4: Multidimensional Well-being Indicators: Dimensions, Cutoffs, and Weights

\begin{tabular}{|c|c|c|c|}
\hline Dimension & Indicator & Cuttoff: Considered deprived if . . . & Weight \\
\hline \multirow[t]{2}{*}{ Health } & Nutrition & $\begin{array}{l}\text { Any member (adult or child) for whom there } \\
\text { is nutritional information is undernourished }\end{array}$ & $1 / 6$ \\
\hline & Child mortality & $\begin{array}{l}\text { Any child has died in the family in the five- } \\
\text { year period preceding the survey }\end{array}$ & $1 / 6$ \\
\hline \multirow[t]{3}{*}{ Education } & Years of schooling & $\begin{array}{l}\text { No household member aged } 10 \text { years or } \\
\text { older has completed six years of schooling }\end{array}$ & $1 / 6$ \\
\hline & School attendance & $\begin{array}{l}\text { Any school-aged child is not attending } \\
\text { school }\end{array}$ & $1 / 6$ \\
\hline & Cooking fuel & $\begin{array}{l}\text { The household cooks with dung, wood, } \\
\text { charcoal or coal }\end{array}$ & $1 / 18$ \\
\hline \multirow[t]{5}{*}{ Living Standards } & Sanitation & $\begin{array}{l}\text { Household lacks adequate sanitation or } \\
\text { their toilet is shared }\end{array}$ & $1 / 18$ \\
\hline & Water & $\begin{array}{l}\text { No access to improved drinking water or } \\
\text { safe drinking water is at least a } 30-\text { minute } \\
\text { walk from home, round trip }\end{array}$ & $1 / 18$ \\
\hline & Electricity & The household has no electricity & $1 / 18$ \\
\hline & Housing & $\begin{array}{l}\text { Floor, roof or walls of dwelling are } \\
\text { constructed using natural materials }\end{array}$ & $1 / 18$ \\
\hline & Assets & $\begin{array}{l}\text { The household does not own more than } \\
\text { one of these assets: radio, TV, telephone, } \\
\text { computer, animal cart, bicycle, motorbike } \\
\text { or refrigerator, and does not own a car or } \\
\text { truck. }\end{array}$ & $1 / 18$ \\
\hline
\end{tabular}

Source: Adopted from Alkire and Jahan (2018). 


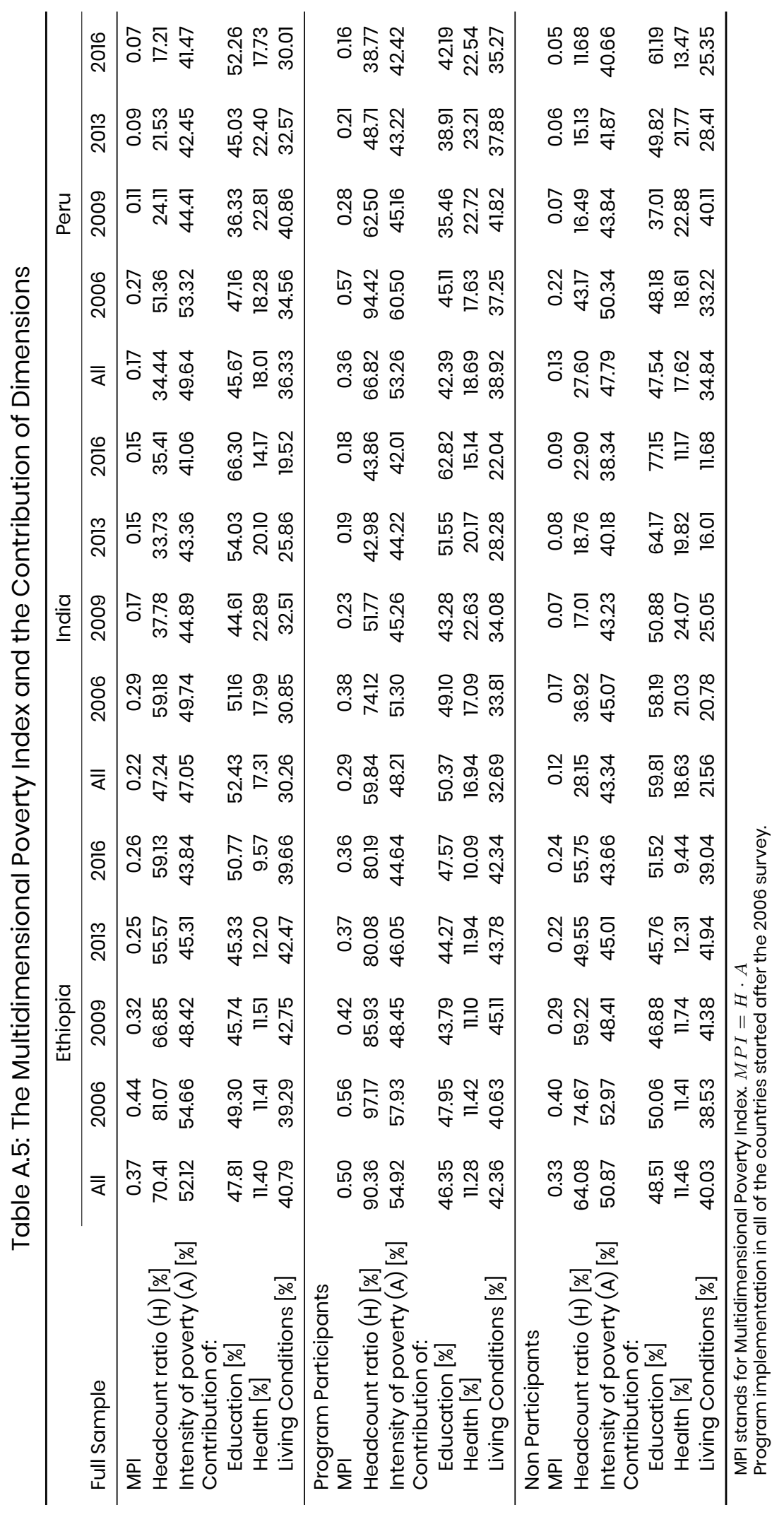


Table A.6: Deprivation in the Multidimensional Poverty Index: Ethiopia

\begin{tabular}{lccccccccc}
\hline & \multicolumn{2}{c}{2006} & \multicolumn{2}{c}{2009} & \multicolumn{2}{c}{2012} & \multicolumn{3}{c}{2016} \\
& Part. & Non-Part. & Part. & Non-Part. & Part. & Non-Part. & Part. & Non-Part. \\
\hline Censored Headcount: Percentage of people who are poor & and deprived in: \\
\hline Schooling & 93.4 & 62.1 & 84.6 & 54.7 & 78.0 & 47.3 & 76.8 & 52.6 \\
Attendance & 68.5 & 56.7 & 24.8 & 25.9 & 19.9 & 14.0 & 25.4 & 22.7 \\
Nutrition & 38.6 & 27.1 & 27.7 & 20.2 & 26.4 & 16.5 & 21.7 & 13.7 \\
Electricity & 79.6 & 45.9 & 69.2 & 38.4 & 44.7 & 30.5 & 43.7 & 26.3 \\
Sanitation & 68.0 & 45.4 & 31.7 & 27.6 & 26.6 & 19.0 & 33.1 & 26.1 \\
Water & 49.0 & 43.7 & 52.7 & 34.9 & 60.0 & 28.4 & 58.2 & 29.0 \\
Housing & 74.9 & 57.1 & 68 & 47.7 & 59.6 & 34.4 & 48.3 & 34.8 \\
Fuel & 97.0 & 71.1 & 85.9 & 58.1 & 79.7 & 48.3 & 79.6 & 51.8 \\
Assets & 43.2 & 11.1 & 30.5 & 6.84 & 20.1 & 7.78 & 9.91 & 2.98 \\
\hline Dimensional Contribution: \% Contribution to MPI of indicator: & & & \\
\hline Schooling & 27.7 & 26.1 & 33.8 & 31.8 & 35.3 & 35.3 & 35.8 & 36.0 \\
Attendance & 20.3 & 23.9 & 9.94 & 15.1 & 9.00 & 10.4 & 11.8 & 15.5 \\
Nutrition & 11.4 & 11.4 & 11.1 & 11.7 & 11.9 & 12.3 & 10.1 & 9.41 \\
Electricity & 7.85 & 6.45 & 9.24 & 7.44 & 6.74 & 7.59 & 6.78 & 6.01 \\
Sanitation & 6.71 & 6.38 & 4.23 & 5.35 & 4.01 & 4.74 & 5.14 & 5.95 \\
Water & 4.83 & 6.14 & 7.03 & 6.76 & 9.03 & 7.07 & 9.03 & 6.62 \\
Housing & 7.40 & 8.02 & 9.07 & 9.25 & 8.97 & 8.56 & 7.50 & 7.95 \\
Fuel & 9.58 & 9.98 & 11.5 & 11.3 & 12.0 & 12.0 & 12.3 & 11.8 \\
Assets & 4.26 & 1.55 & 4.07 & 1.33 & 3.03 & 1.94 & 1.54 & 0.68 \\
\hline
\end{tabular}


Table A.7: Deprivation in the Multidimensional Poverty Index: Peru

\begin{tabular}{lccccccccc}
\hline & \multicolumn{2}{c}{2006} & \multicolumn{2}{c}{2009} & \multicolumn{2}{c}{2012} & \multicolumn{2}{c}{2016} \\
& Part. & Non-Part. & Part. & Non-Part. & Part. & Non-Part. & Part. & Non-Part. \\
\hline Censored Headcount: Percentage of people who are poor & and deprived in: \\
\hline Schooling & 75 & 25.5 & 59.1 & 14.3 & 44.8 & 12.3 & 36.1 & 10.5 \\
Attendance & 79.6 & 35.9 & 0.98 & 1.75 & 4.31 & 6.57 & 5.51 & 6.95 \\
Nutrition & 60.4 & 24.1 & 38.5 & 9.92 & 29.3 & 8.25 & 22.2 & 3.84 \\
Electricity & 51.5 & 15.8 & 26.5 & 6.32 & 6.68 & 2.49 & 4.19 & 1.75 \\
Sanitation & 31.3 & 9.52 & 9.07 & 3.50 & 7.76 & 2.44 & 3.96 & 1.36 \\
Water & 55.6 & 25.5 & 24.0 & 8.12 & 24.4 & 6.11 & 19.8 & 4.92 \\
Housing & 90.5 & 33.4 & 61.5 & 14.3 & 47.2 & 10.3 & 37.2 & 7.01 \\
Fuel & 93.4 & 31.4 & 60.8 & 14.3 & 46.3 & 9.16 & 34.4 & 5.54 \\
Assets & 60.7 & 12.8 & 30.6 & 5.59 & 11.2 & 1.99 & 4.85 & 0.90 \\
\hline Dimensional Contribution: \% Contribution to MPI of indicator: & & & \\
\hline Schooling & 21.9 & 19.9 & 34.9 & 33.0 & 35.5 & 32.5 & 36.6 & 36.8 \\
Attendance & 23.2 & 28.0 & 0.58 & 4.04 & 3.41 & 17.3 & 5.58 & 24.5 \\
Nutrition & 17.6 & 18.8 & 22.7 & 22.9 & 23.2 & 21.7 & 22.5 & 13.5 \\
Electricity & 5.00 & 4.12 & 5.21 & 4.86 & 1.76 & 2.19 & 1.41 & 2.06 \\
Sanitation & 3.05 & 2.47 & 1.78 & 2.69 & 2.05 & 2.15 & 1.34 & 1.59 \\
Water & 5.41 & 6.62 & 4.73 & 6.24 & 6.43 & 5.36 & 6.70 & 5.77 \\
Housing & 8.81 & 8.69 & 12.1 & 11.0 & 12.5 & 9.03 & 12.6 & 8.22 \\
Fuel & 9.09 & 8.15 & 12.0 & 11.0 & 12.2 & 8.05 & 11.6 & 6.50 \\
Assets & 5.90 & 3.32 & 6.03 & 4.30 & 2.96 & 1.74 & 1.64 & 1.06 \\
\hline
\end{tabular}


Table A.8: Deprivation in the Multidimensional Poverty Index: India

\begin{tabular}{lcccccccc}
\hline & \multicolumn{2}{c}{2006} & \multicolumn{2}{c}{2009} & \multicolumn{2}{c}{2012} & \multicolumn{2}{c}{2016} \\
& Part. & Non-Part. & Part. & Non-Part. & Part. & Non-Part. & Part. & Non-Part. \\
\hline Censored Headcount: & Percentage of & people who & are poor & and deprived in: & \\
\hline Schooling & 52.2 & 45.6 & 37.0 & 32.3 & 26.8 & 25.7 & 35.5 & 32.0 \\
Attendance & 43.3 & 35.4 & 11.8 & 6.71 & 3.37 & 2.72 & 24.3 & 21.6 \\
Nutrition & 34.1 & 27.7 & 24.7 & 21.0 & 20.6 & 18.6 & 13.8 & 10.3 \\
Electricity & 6.78 & 15.1 & 1.67 & 4.41 & 1.23 & 3.18 & 1.09 & 1.25 \\
Sanitation & 51.7 & 44.3 & 35.6 & 31.0 & 24.0 & 23.9 & 23.9 & 24.7 \\
Water & 2.56 & 7.81 & 0.91 & 5.11 & 0.16 & 1.97 & 0.11 & 1.77 \\
Housing & 25.9 & 25 & 16.4 & 18.8 & 8.62 & 10.7 & 7.47 & 7.91 \\
Fuel & 55.3 & 46.9 & 37.5 & 31.3 & 22.9 & 23.6 & 18.2 & 15.7 \\
Assets & 23.4 & 20.5 & 7.27 & 8.72 & 2.22 & 5.30 & 0.57 & 1.04 \\
\hline Dimensional Contribution: \% Contribution to MPI of indicator: & & & \\
\hline Schooling & 28.3 & 28.2 & 34.7 & 34.6 & 38.0 & 36.8 & 39.1 & 39.4 \\
Attendance & 23.4 & 21.9 & 11.1 & 7.21 & 4.78 & 3.89 & 26.8 & 26.6 \\
Nutrition & 18.4 & 17.1 & 23.1 & 22.6 & 29.3 & 26.6 & 15.2 & 12.6 \\
Electricity & 1.22 & 3.11 & 0.52 & 1.58 & 0.58 & 1.51 & 0.40 & 0.51 \\
Sanitation & 9.32 & 9.12 & 11.1 & 11.1 & 11.3 & 11.4 & 8.79 & 10.1 \\
Water & 0.46 & 1.61 & 0.29 & 1.83 & 0.078 & 0.94 & 0.042 & 0.72 \\
Housing & 4.68 & 5.15 & 5.12 & 6.74 & 4.08 & 5.12 & 2.75 & 3.24 \\
Fuel & 9.98 & 9.67 & 11.7 & 11.2 & 10.8 & 11.2 & 6.68 & 6.43 \\
Assets & 4.22 & 4.21 & 2.27 & 3.12 & 1.05 & 2.52 & 0.21 & 0.43 \\
\hline
\end{tabular}




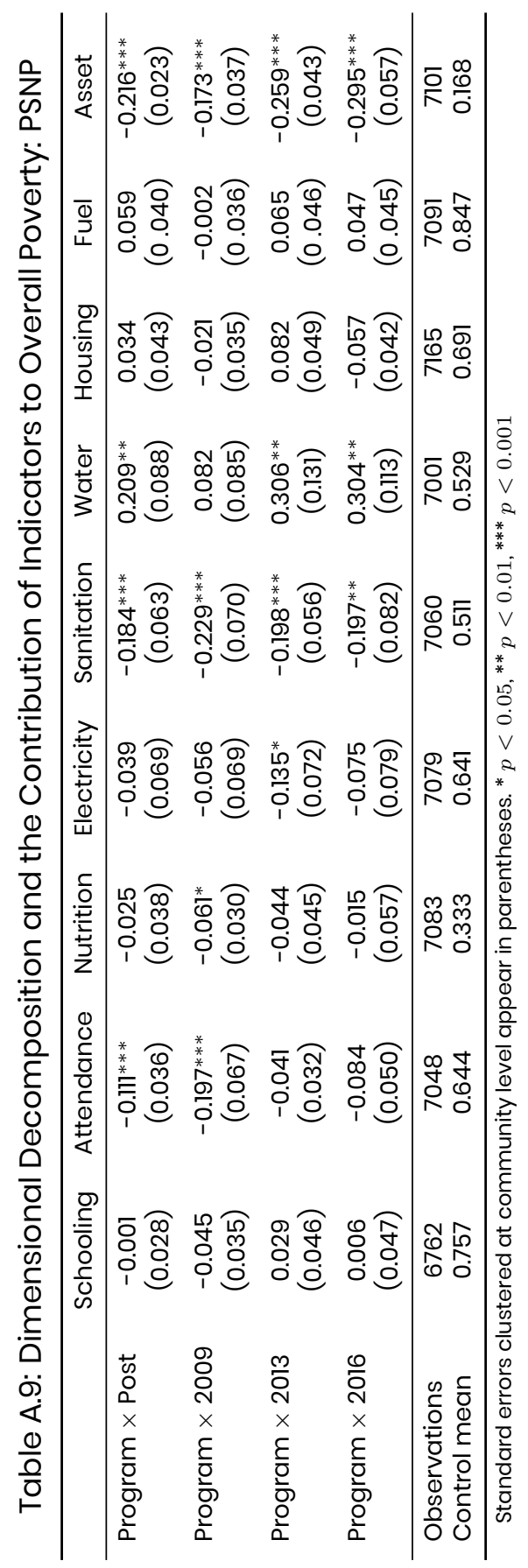




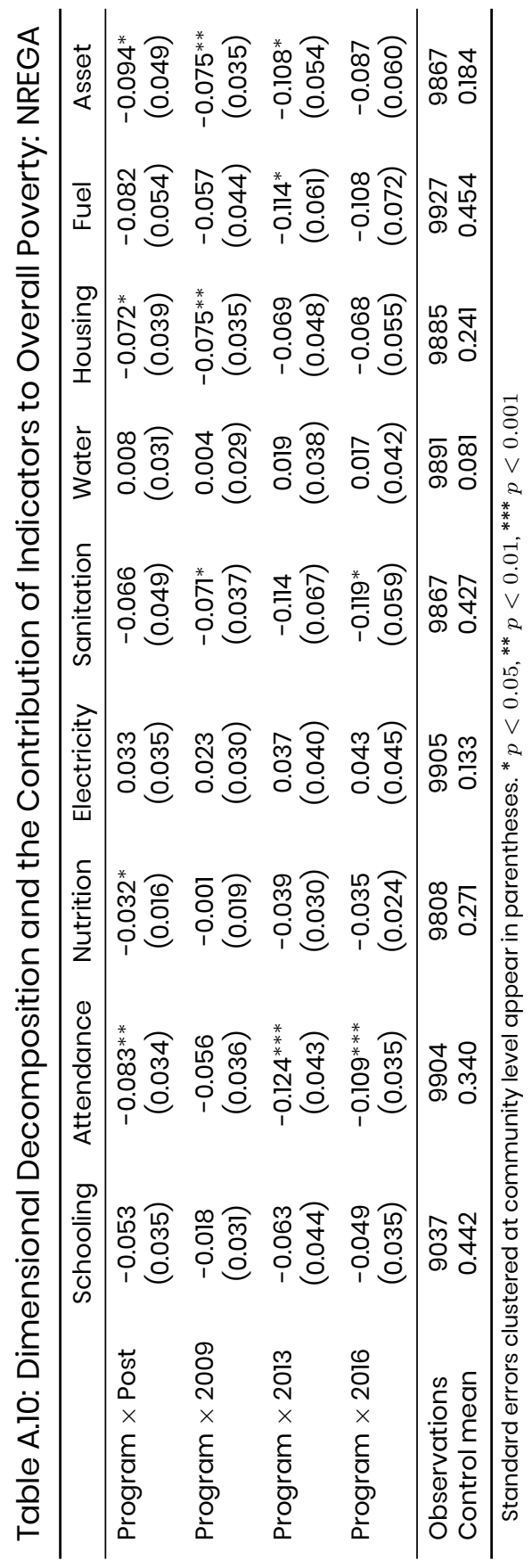




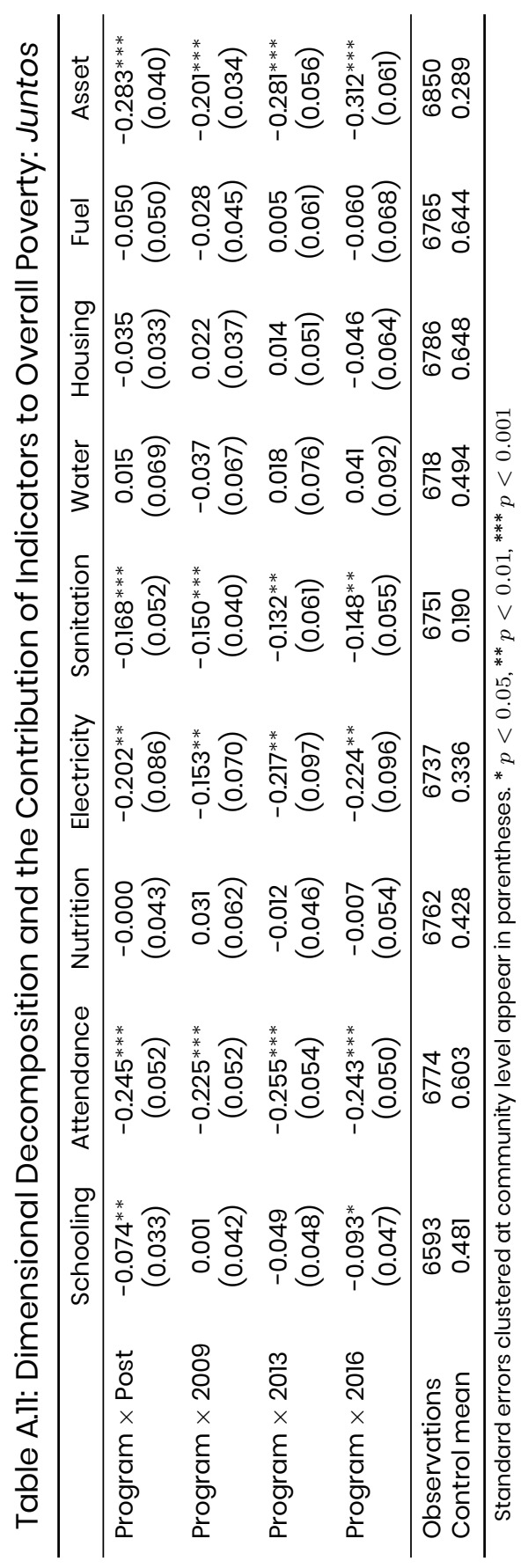


Table A.12: DID Estimations: Short- and Longer-run Effects

\begin{tabular}{|c|c|c|c|c|}
\hline & \multirow{2}{*}{ Livestock } & \multirow{2}{*}{ "Wealth" } & \multicolumn{2}{|c|}{ Susceptibility to shock } \\
\hline & & & Natural & Economic \\
\hline \multicolumn{5}{|l|}{ Ethiopia } \\
\hline Program $\times$ Post & $\begin{array}{l}0.122^{* *} \\
(0.047)\end{array}$ & $\begin{array}{l}-0.005 \\
(0.015)\end{array}$ & $\begin{array}{c}-0.031 \\
(0.065)\end{array}$ & $\begin{array}{c}0.123 \\
(0.072)\end{array}$ \\
\hline Program ×2009 & $\begin{array}{l}0.137^{* * *} \\
(0.033)\end{array}$ & $\begin{array}{c}0.020 \\
(0.015)\end{array}$ & $\begin{array}{c}-0.016 \\
(0.086)\end{array}$ & $\begin{array}{c}0.035 \\
(0.082)\end{array}$ \\
\hline Program $\times 2016$ & $\begin{array}{l}0.157^{* * *} \\
(0.055)\end{array}$ & $\begin{array}{l}0.006 \\
(0.021)\end{array}$ & $\begin{array}{l}0.036 \\
(0.110)\end{array}$ & $\begin{array}{c}0.016 \\
(0.084)\end{array}$ \\
\hline \multicolumn{5}{|l|}{ India } \\
\hline Program $\times$ Post & $\begin{array}{c}0.051 \\
(0.032)\end{array}$ & $\begin{array}{c}0.013 \\
(0.021)\end{array}$ & $\begin{array}{c}-0.162^{* *} \\
(0.076)\end{array}$ & $\begin{array}{l}-0.125^{*} \\
(0.062)\end{array}$ \\
\hline Program×2009 & $\begin{array}{c}0.070^{* * *} \\
(0.019)\end{array}$ & $\begin{array}{c}0.017 \\
(0.014)\end{array}$ & $\begin{array}{c}-0.192^{* *} \\
(0.077)\end{array}$ & $\begin{array}{l}-0.091 \\
(0.065)\end{array}$ \\
\hline Program $\times 2016$ & $\begin{array}{c}-0.021 \\
(0.033)\end{array}$ & $\begin{array}{c}0.017 \\
(0.029)\end{array}$ & $\begin{array}{c}-0.062 \\
(0.109)\end{array}$ & $\begin{array}{c}-0.106 \\
(0.084)\end{array}$ \\
\hline \multicolumn{5}{|l|}{ Peru } \\
\hline Program $\times$ Post & $\begin{array}{c}0.232^{* * *} \\
(0.045)\end{array}$ & $\begin{array}{l}-0.019 \\
(0.016)\end{array}$ & $\begin{array}{l}-0.007 \\
(0.066)\end{array}$ & $\begin{array}{l}-0.005 \\
(0.031)\end{array}$ \\
\hline Program ×2009 & $\begin{array}{l}0.122^{* * *} \\
(0.025)\end{array}$ & $\begin{array}{c}0.013 \\
(0.014)\end{array}$ & $\begin{array}{c}-0.014 \\
(0.081)\end{array}$ & $\begin{array}{c}0.023 \\
(0.040)\end{array}$ \\
\hline Program $\times 2016$ & $\begin{array}{c}0.296 * * * \\
(0.056)\end{array}$ & $\begin{array}{l}-0.021 \\
(0.019)\end{array}$ & $\begin{array}{c}0.103 \\
(0.089)\end{array}$ & $\begin{array}{l}-0.006 \\
(0.042)\end{array}$ \\
\hline
\end{tabular}

Each cell is from a separate DID estimation of the outcome variable indicated in the column headings. Cluster robust standard errors appear in parentheses. ${ }^{*} p<0.01,{ }^{* *} p<0.05,{ }^{* * *} p<0.001$

Table A.13: Short- and Longer-run effects of NREGA: PS-DID Estimations

\begin{tabular}{cccccc}
\hline & \multicolumn{2}{c}{ Incidence of Poverty } & & Intensity of Poverty \\
\cline { 2 - 3 } \cline { 5 - 6 } & $k=33 \%$ & $k=50 \%$ & & $k=33 \%$ & $k=50 \%$ \\
\hline Program $\times$ Post & $-0.089^{* * *}$ & $-0.166^{* * *}$ & $-0.073^{* * *}$ & $-0.105^{* * *}$ \\
& $(0.026)$ & $(0.025)$ & $(0.012)$ & $(0.016)$ \\
Program $\times 2009$ & $-0.077^{* * *}$ & $-0.143^{* * *}$ & $-0.047^{* * *}$ & $-0.104^{* * *}$ \\
& $(0.026)$ & $(0.026)$ & $(0.011)$ & $(0.021)$ \\
Program $\times 2013$ & $-0.088^{*}$ & $-0.183^{* * *}$ & $-0.077^{* * *}$ & $-0.118^{* * *}$ \\
& $(0.045)$ & $(0.034)$ & $(0.020)$ & $(0.020)$ \\
Program $\times$ Post & $-0.127^{* * *}$ & $-0.192^{* * *}$ & $-0.073^{* * *}$ & $-0.122^{* * *}$ \\
& $(0.044)$ & $(0.031)$ & $(0.021)$ & $(0.019)$ \\
Observations & 9479 & 9487 & 9486 & 9571 \\
Control mean & 0.474 & 0.210 & 0.228 & 0.126 \\
\hline
\end{tabular}

Each cell is from a separate DID estimation of the outcome variable indicated in the column headings. Cluster robust standard errors in parenthesis.

${ }^{*} p<0.01,{ }^{* *} p<0.05,{ }^{* * *} p<0.001$ 
Table A.14: Short and Longer term effects of NREGA: ATE estimations

\begin{tabular}{cccccc}
\hline & \multicolumn{2}{c}{ Incidence of Poverty } & & Intensity of Poverty \\
\cline { 2 - 3 } \cline { 5 - 6 } & $k=33 \%$ & $k=50 \%$ & & $k=33 \%$ & $k=50 \%$ \\
\hline Program $\times$ Post & -0.029 & $-0.188^{* * *}$ & & $-0.072^{* * *}$ & $-0.110^{* * *}$ \\
& $(0.023)$ & $(0.025)$ & & $(0.011)$ & $(0.016)$ \\
Program $\times 2009$ & $-0.062^{*}$ & $-0.158^{* * *}$ & $-0.052^{* * *}$ & $-0.087^{* * *}$ \\
& $(0.035)$ & $(0.028)$ & $(0.013)$ & $(0.021)$ \\
Program $\times 2013$ & -0.081 & $-0.179^{* * *}$ & $-0.077^{* * *}$ & $-0.114^{* * *}$ \\
& $(0.054)$ & $(0.032)$ & $(0.021)$ & $(0.022)$ \\
Program $\times 2016$ & $-0.094^{* *}$ & $-0.205^{* * *}$ & $-0.096^{* * *}$ & $-0.116^{* * *}$ \\
& $(0.033)$ & $(0.030)$ & $(0.017)$ & $(0.020)$ \\
Observations & 8717 & 9543 & & 9580 & 9573 \\
Control mean & 0.474 & 0.210 & 0.228 & 0.126
\end{tabular}

Each cell is from a separate DID estimation of the outcome variable indicated in the column headings. Cluster robust standard errors appear in parentheses.

${ }^{*} p<0.01,{ }^{* *} p<0.05,{ }^{* * *} p<0.001$

Table A.15: Robustness check: Placebo program implementation

\begin{tabular}{cccccc}
\hline & \multicolumn{2}{c}{ Incidence of Poverty } & & \multicolumn{2}{c}{ Intensity of Poverty } \\
\cline { 2 - 3 } \cline { 5 - 6 } & $k=33 \%$ & $k=50 \%$ & & $k=33 \%$ & $k=50 \%$ \\
\hline PSNP $\times$ Post & $0.053^{*}$ & 0.029 & 0.011 & -0.001 \\
& $(0.029)$ & $(0.040)$ & & $(0.019)$ & $(0.032)$ \\
Observations & 5265 & 5265 & 5265 & 5265 \\
NREGA $\times$ Post & 0.070 & 0.075 & 0.044 & $0.049 *$ \\
& $(0.047)$ & $(0.050)$ & $(0.026)$ & $(0.026)$ \\
Observations & 5636 & 5636 & 5636 & 5636 \\
Juntos $\times$ Post & $0.084^{*}$ & 0.077 & -0.027 & 0.050 \\
& $(0.044)$ & $(0.047)$ & $(0.024)$ & $(0.038)$ \\
Observations & 3471 & 3471 & 3471 & 3471 \\
\hline
\end{tabular}

Standard errors in parentheses

${ }^{*} p<0.10,{ }^{* *} p<0.05,{ }^{* * *} p<0.01$ 
Table A.16: Rbustness Checks: DID Estimations Without Controls

\begin{tabular}{|c|c|c|c|c|}
\hline & \multicolumn{2}{|c|}{ Incidence of Poverty } & \multicolumn{2}{|c|}{ Intensity of Poverty } \\
\hline & $k=33 \%$ & $k=50 \%$ & $k=33 \%$ & $k=50 \%$ \\
\hline \multicolumn{5}{|l|}{ Ethiopia } \\
\hline Program $\times$ Post & $\begin{array}{l}0.070 * \\
(0.032)\end{array}$ & $\begin{array}{c}-0.106^{* * *} \\
(0.032)\end{array}$ & $\begin{array}{c}-0.033^{* *} \\
(0.012)\end{array}$ & $\begin{array}{c}-0.096^{* * *} \\
(0.017)\end{array}$ \\
\hline Program $\times 2009$ & $\begin{array}{c}0.030 \\
(0.037)\end{array}$ & $\begin{array}{c}-0.199 * * * \\
(0.048)\end{array}$ & $\begin{array}{c}-0.059^{* * *} \\
(0.014)\end{array}$ & $\begin{array}{c}-0.146 * * * \\
(0.020)\end{array}$ \\
\hline Program $\times 2013$ & $\begin{array}{l}0.090^{*} \\
(0.045)\end{array}$ & $\begin{array}{c}-0.079 * * \\
(0.028)\end{array}$ & $\begin{array}{l}-0.006 \\
(0.014)\end{array}$ & $\begin{array}{c}-0.071^{* * *} \\
(0.021)\end{array}$ \\
\hline Program $\times 2016$ & $\begin{array}{l}0.088^{*} \\
(0.036)\end{array}$ & $\begin{array}{l}-0.072 \\
(0.045)\end{array}$ & $\begin{array}{l}-0.023 \\
(0.021)\end{array}$ & $\begin{array}{c}-0.067^{* *} \\
(0.027)\end{array}$ \\
\hline $\begin{array}{l}\text { Observations } \\
\text { Control mean }\end{array}$ & $\begin{array}{l}7142 \\
0.86\end{array}$ & $\begin{array}{l}7033 \\
0.60\end{array}$ & $\begin{array}{l}7198 \\
0.48\end{array}$ & $\begin{array}{l}7125 \\
0.38\end{array}$ \\
\hline \multicolumn{5}{|l|}{ India } \\
\hline Program $\times$ Post & $\begin{array}{c}-0.060^{*} \\
(0.031)\end{array}$ & $\begin{array}{c}-0.098^{*} \\
(0.048)\end{array}$ & $\begin{array}{l}-0.033 \\
(0.024)\end{array}$ & $\begin{array}{c}-0.054 * \\
(0.031)\end{array}$ \\
\hline Program $\times 2009$ & $\begin{array}{c}-0.050^{* *} \\
(0.022)\end{array}$ & $\begin{array}{c}-0.080 * \\
(0.044)\end{array}$ & $\begin{array}{r}-0.031^{*} \\
(0.018)\end{array}$ & $\begin{array}{l}-0.038 \\
(0.027)\end{array}$ \\
\hline Program × 2013 & $\begin{array}{c}-0.117^{* *} \\
(0.051)\end{array}$ & $\begin{array}{c}-0.123^{* *} \\
(0.053)\end{array}$ & $\begin{array}{c}-0.062^{* *} \\
(0.027)\end{array}$ & $\begin{array}{c}-0.068^{*} \\
(0.033)\end{array}$ \\
\hline Program × 2016 & $\begin{array}{c}-0.092^{*} \\
(0.047)\end{array}$ & $\begin{array}{l}-0.107^{*} \\
(0.055)\end{array}$ & $\begin{array}{c}-0.044^{*} \\
(0.026)\end{array}$ & $\begin{array}{l}-0.043 \\
(0.038)\end{array}$ \\
\hline $\begin{array}{l}\text { Observations } \\
\text { Control mean }\end{array}$ & $\begin{array}{c}9082 \\
0.51\end{array}$ & $\begin{array}{l}9879 \\
0.25\end{array}$ & $\begin{array}{c}9886 \\
0.26\end{array}$ & $\begin{array}{c}9880 \\
0.16\end{array}$ \\
\hline \multicolumn{5}{|l|}{ Peru } \\
\hline Program $\times$ Post & $\begin{array}{c}-0.017 \\
(0.044)\end{array}$ & $\begin{array}{c}-0.287^{* * *} \\
(0.058)\end{array}$ & $\begin{array}{c}-0.117^{* * *} \\
(0.027)\end{array}$ & $\begin{array}{c}-0.219 * * * \\
(0.037)\end{array}$ \\
\hline Program $\times 2009$ & $\begin{array}{c}0.023 \\
(0.045)\end{array}$ & $\begin{array}{c}-0.254^{* * *} \\
(0.056)\end{array}$ & $\begin{array}{c}-0.082^{* * *} \\
(0.027)\end{array}$ & $\begin{array}{c}-0.182 * * * \\
(0.039)\end{array}$ \\
\hline Program × 2013 & $\begin{array}{l}-0.034 \\
(0.045)\end{array}$ & $\begin{array}{c}-0.285^{* * *} \\
(0.066)\end{array}$ & $\begin{array}{c}-0.120^{* * *} \\
(0.028)\end{array}$ & $\begin{array}{c}-0.222^{* * *} \\
(0.043)\end{array}$ \\
\hline Program × 2016 & $\begin{array}{l}-0.084 \\
(0.054)\end{array}$ & $\begin{array}{c}-0.310^{* * *} \\
(0.056)\end{array}$ & $\begin{array}{c}-0.129^{* * *} \\
(0.033)\end{array}$ & $\begin{array}{c}-0.223^{* * *} \\
(0.040)\end{array}$ \\
\hline Observations & 6563 & 6698 & 6752 & 6757 \\
\hline Control mean & 0.72 & 0.48 & 0.40 & 0.30 \\
\hline
\end{tabular}

Each cell is from a separate DID estimation of the outcome variable indicated in the column headings. Cluster robust standard errors in parentheses. ${ }^{*} p<0.01,{ }^{* *} p<0.05,{ }^{* * *} p<0.001$ 


\section{B. Additional Figures}

Figure B.l: Trends in the Incidence and Intensity of Multidimensional Poverty, by Participation Status
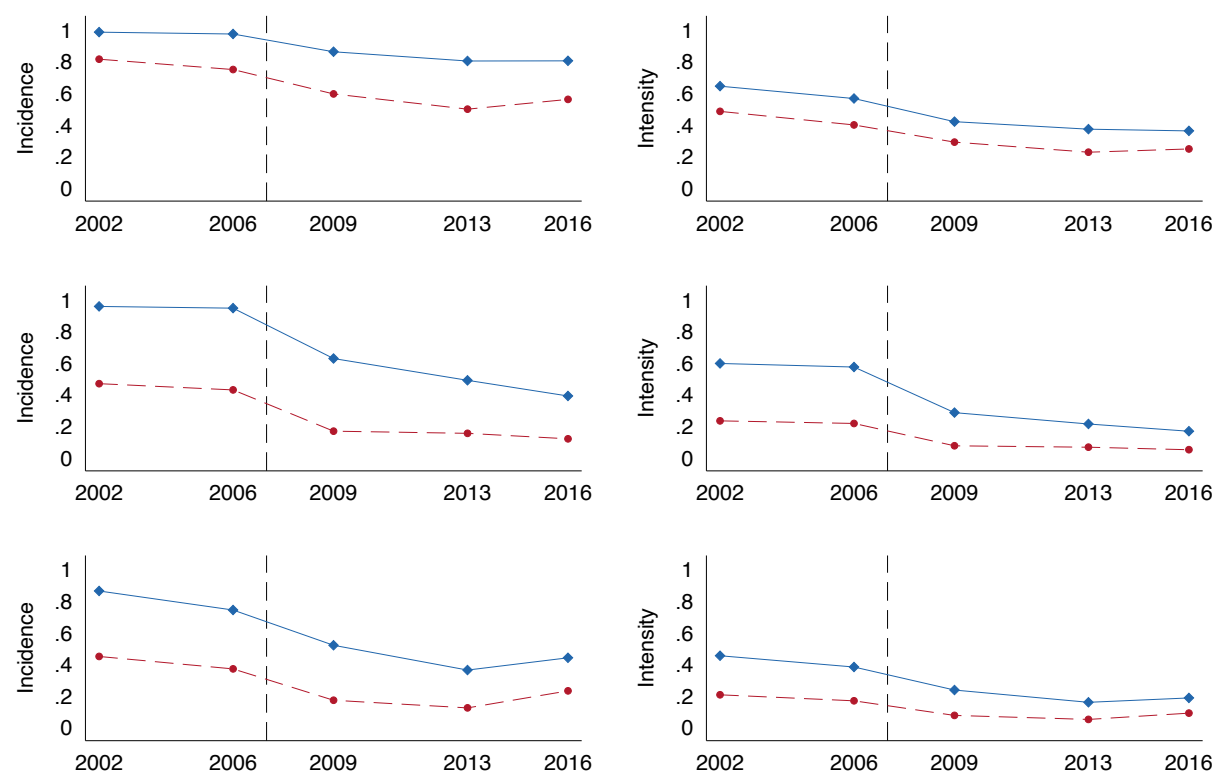

$\leftarrow$ Participants $\rightarrow$ Non-participants
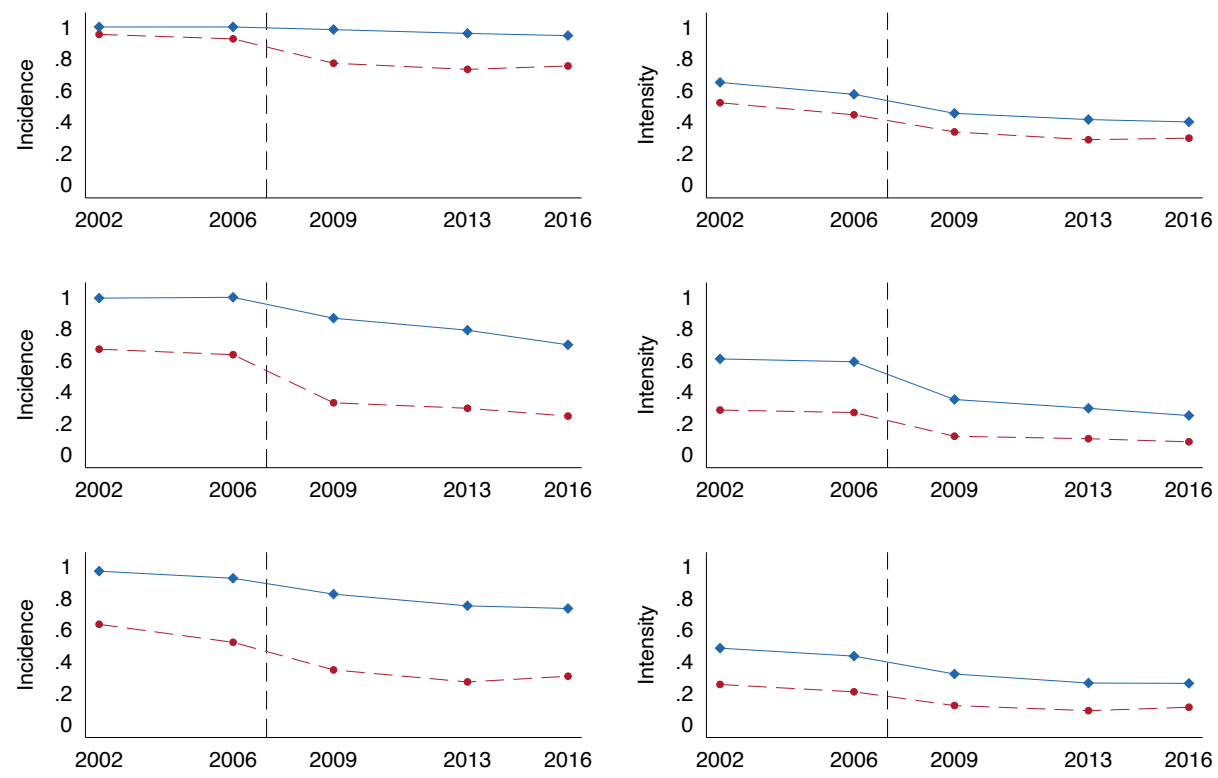

Participants $\rightarrow$ Non-participants

Note: The incidence and intensity of MPI are calculated based on a deprivation cutoff of $33 \%$ (top panel) and $20 \%$ (bottom panel) of the weighted indicators. 
Figure B.2: Trends in Wealth Index and Asset Ownership, by Participation Status
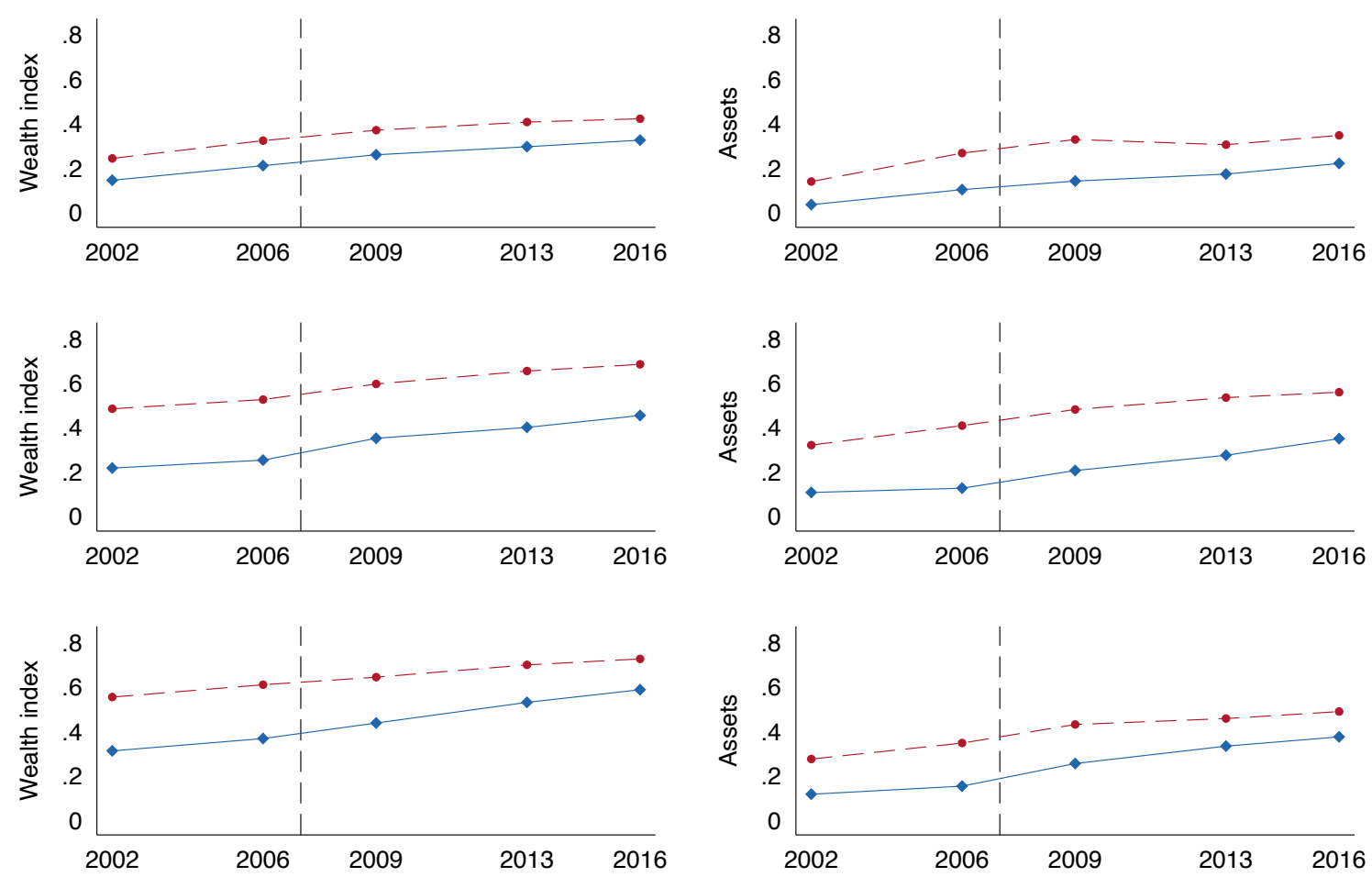

$\leftrightarrow$ Participants

Non-participants 


\begin{abstract}
What is AFD?
The Agence Française de Développement (AFD) Group is a public entity which finances, supports and expedites transitions toward a more just and sustainable world. As a French overseas aid platform for sustainable development and investment, we and our partners create shared solutions, with and for the people of the global South.

Active in more than 4,000 projects in the French overseas departments and some 115 countries, our teams strive to promote health, education and gender equality, and are working to protect our common resources - peace, education, health, biodiversity and a stable climate. It's our way of honoring the commitment France and the French people have made to fulfill the Sustainable Development Goals.

Towards a world in common.
\end{abstract}

Publication Director Rémy Rioux Editor-in-Chief Thomas Melonio

Legal deposit 3rd quarter 2020

ISSN 2492 - 2846 C AFD

Graphic design MeMo, Juliegilles, D. Cazeils Layout AFD

Printed by the AFD reprography service 